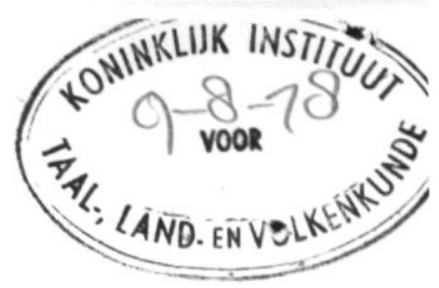

\title{
THE ORIGINS OF THE GAAN GADU MOVEMENT OF THE BUSH NEGROES OF SURINAM
}

In the early 1890s, the Bush Negroes of Surinam's coastal plain were restive. From the far-away Tapanahoni, the heartland of the Djuka Bush Negroes, ${ }^{1}$ word had reached them of the appearance of a powerful and vindictive God called Gaan Gadu (Great Deity) or Gaan Tata (Great Father). ${ }^{2}$ This God, they were told, would wage unrelenting war on the witches. The cadavers of such nefarious persons would be dumped into the undergrowth along certain creeks where carrion birds would pick out their eyes and caimans tear at their bowels. All possessions of those who, upon their death, were believed to be witches were to be confiscated by Gaan Gadu's priests and carried to Santi Goon on the Tapanahoni, the god's sacred bush shrine.

In 1891 the first tidings came almost simultaneously from two different places. Carpenters building a mission post on the Cottica river reported that there had been a gathering of hundreds of Bush Negroes in the nearby village of Moarimbomoffo (see fig. 1), where emissaries from the Tapanahoni had disclosed Gaan Gadu's commandments. These instructions concerned many spheres of life, from religious worship to marital relationships (BHW 1892: 142). At Koffiekamp, a small Christian community near the confluence of Sara creek and Suriname river, a missionary heard similar news (BHW 1892: 139-141). Here, the messengers from the Tapanahoni warned the heathen majority of the Djuka, located in the Sara creek region, that all places of worship should thereafter be dedicated solely to Gaan Gadu. All the old obi or obia were to be 
thrown into the river or burnt in fire, and shrines of the 'false gods' of the past demolished.

The new movement made rapid headway. By 1893 it had established itself as the most powerful cult in Djuka communities of the coastal plain. Soon it made inroads into the territory of other tribal groups as well. A few years before the turn of the century, the new ritual centres on the Tapanahoni drew scores of believers from Saramaka villages (Spalburg 1869-1900). ${ }^{3}$ In 1893, Gaan Gadu's priests made converts among the Matawai, no small accomplishment as this had been the first tribal group to embrace Christianity a few decades earlier. In 1895, in the far west, even the small and remote group of Kwinti came under the spell of Gaan Gadu (Kraag 1894-1896).

From the beginning the village of Santigron, with its mixed population of Djuka, Saramaka and Matawai, was a stronghold of Gaan Gadu. It was from here that Gaan Gadu's advocates travelled south to Matawai villages in 1892 and 1893. Its location less than twenty kilometers from Paramaribo, the capital of Surinam, made Santigron a place of pilgrimage for many city Creoles who had heard about the new god's reputation (De Ziel 1973: 40). Special expeditions were organized by Christian missions to preach against the 'false god' and undo the impact of Gaan Gadu's message on their Matawai following (BHW 1895: 12-42). Despite their efforts to wipe out the cult from what they considered a Christian preserve, the missionaries were only partly successful; a quarter of a century later Gaan Gadu was still worshipped in secret in a few Matawai villages. ${ }^{4}$

Around 1895, lines of communication had been established among the various oracles and shrines of Gaan Gadu. Leading priests at the Tapanahoni centres kept in touch with Saramaka acolytes in villages on the Suriname river and its tributaries (NB 1904: 255). Messengers travelled from the Tapanahoni to the men in charge at the Cottica shrines in the northeastern part of the country. These priests in turn were in communication with colleagues in the northwest and west, in places such as Santigron (NB 1892: 574) and Kriki-Pandasi on the Sara 
creek (MBB 1893: 181). Even in the 1920s, there were still lines of communication with Sara creek villagers and with a Saramaka village on the Pikin Rio, a tributary of the Suriname river (Junker 1923).

The organization of the cult was centralized and hierarchical. Bush Negroes from other rivers visited the ritual centre on the Tapanahoni. Hegemony was also asserted through the constant flow of tribute to the Tapanahoni shrines. In 1894, every settlement on the Cottica and Commewijne rivers which boasted of a headman, had to pay a special tax of 128 florins (then US \$ 51) to the Gaan Gadu priests of the Tapanahoni (MBB 1895: 53). In 1917, a small Saramaka village paid 320 florins for the right to open a Gaan Gadu shrine, an enormous sum of money at that time, more than what most labourers in Paramaribo would earn in a whole year (Junker 1925: 154). A new religious duty obligated followers to bring the material legacies of deceased witches to the Tapanahoni shrines (MT 1896: 76). Leerdam (1957: April 23) observed how the effects of the dead found guilty of witchcraft were transported with great difficulty from the Sara creek valley to Dritabiki on the Tapanahoni. ${ }^{5}$

No religious movement of the Bush Negroes ever met with so much success as the Gaan Gadu cult. For three decades, it enjoyed great influence in all the Bush Negro regions of the interior. After 1920, its fortunes began to ebb; what was once a vigorous regional cult fractured into a number of local congregations (Thoden van Velzen 1977). Lines of communication were disrupted and the Tapanahoni centre began to lose control over its various branches in other parts of Surinam. Yet, decades later, the Gaan Gadu oracles continued to be paramount in the Tapanahoni region. In the 1960s, parochial, but thriving Gaan Gadu cults attracted scores of patients and supplicants. During 1962, the oracle at Dritabiki was consulted on approximately 125 days regarding a total of 424 cases. Most of the clientele of the oracle were residents of Tapanahoni villages, while only a sprinkling came from other Djuka areas or from the Saramaka and Aluku Bush Negroes. 


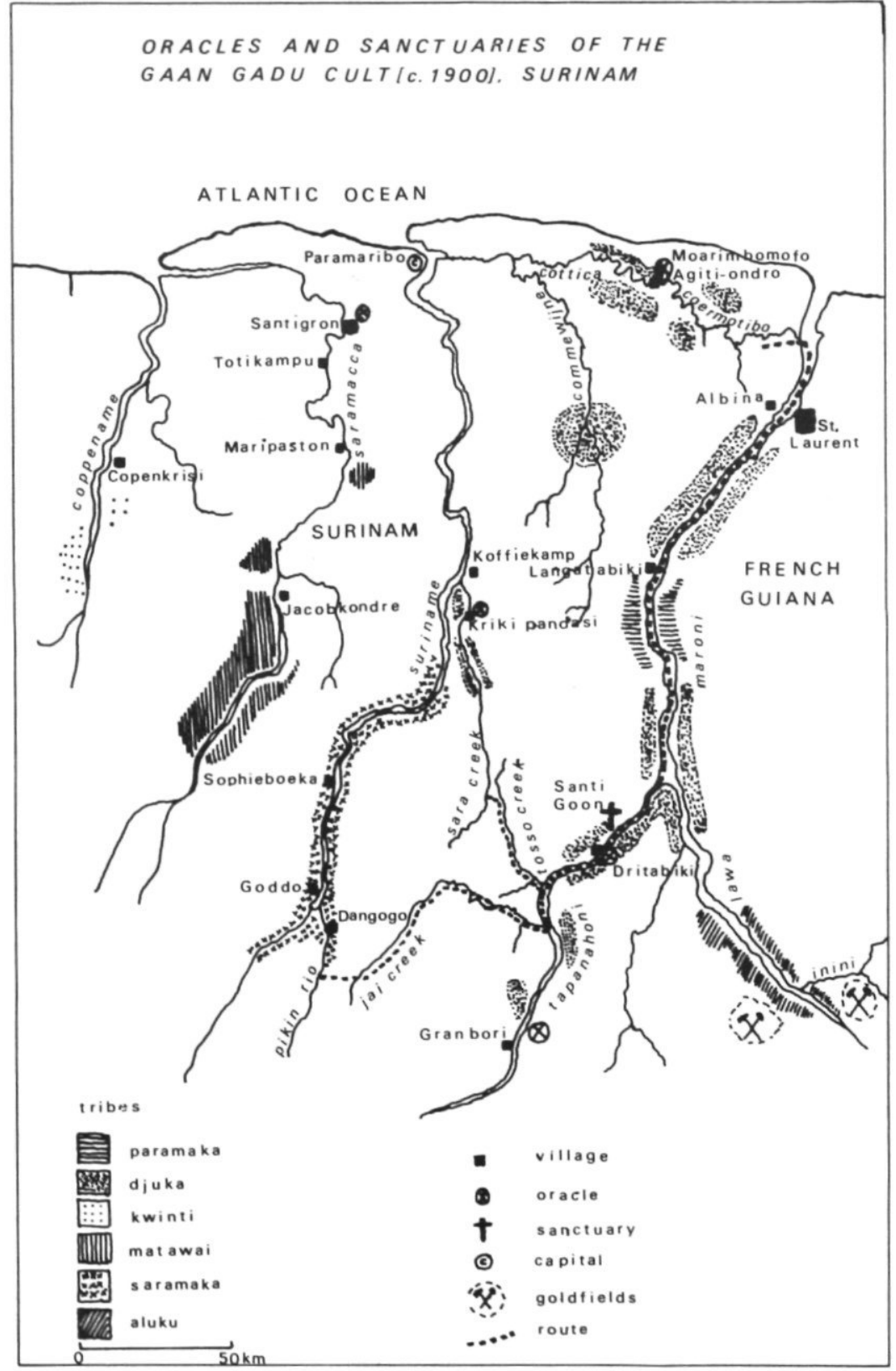

Fig. 1. Oracles and sanctuaries of the Gaan Gadu cult (c. 1900). Surinam. 
In view of the expansion and vigour of the Gaan Gadu cult, it is not astounding that it received a great deal of attention from missionaries, civil servants and anthropologists. Today a list of all publications referring to the movement would be several pages long. However, there is very little to learn from these sources about the early history of the movement, its causes and the events that triggered it. In fact, we are offered contradictory information even about the time of its ascent. Some mention 1879 as the year of its birth (Voorhoeve \& van Renselaar 1962: 203), others 1891 (Schneider 1893: 64; Steinberg 1933: 267 ) or 1890 (Van Panhuys 1908: 38).

The reasons for these unresolved problems are not difficult to grasp. Very few Europeans visited the remote Tapanahoni at the end of the 19th century and, of those who did, few cared to leave written accounts of their sojourns. Gold-diggers passing through the area were too much in a hurry and had other aims to pursue. The publications available ${ }^{6}$ offer a few interesting clues, but none of them renders a full account of the beginnings of the cult.

A later generation of writers on Bush Negro society tried their hand at historical reconstruction. Their theories roughly fall into two categories. On the one hand, there are those that stress continuity, explaining events as the outcome of a power struggle between two Djuka leaders which was compounded by the intervention of the colonial administration. An opposing set of interpretations points to a revolutionary break in the religious history of the Djuka Bush Negroes. I will review both theories briefly, before presenting new material from archival and oral sources on the early history of the Gaan Gadu cult. ${ }^{7}$

\section{The continuity thesis}

Willem van Lier opened the discussion in 1919 with his Iets over de Boschnegers in de Boven-Marowijne (Some Facts about the Bush Negroes of the Upper Maroni), a delightful little book that covered approximately the half century before 1920. Van Lier employed concepts such as 'aristocrats', 


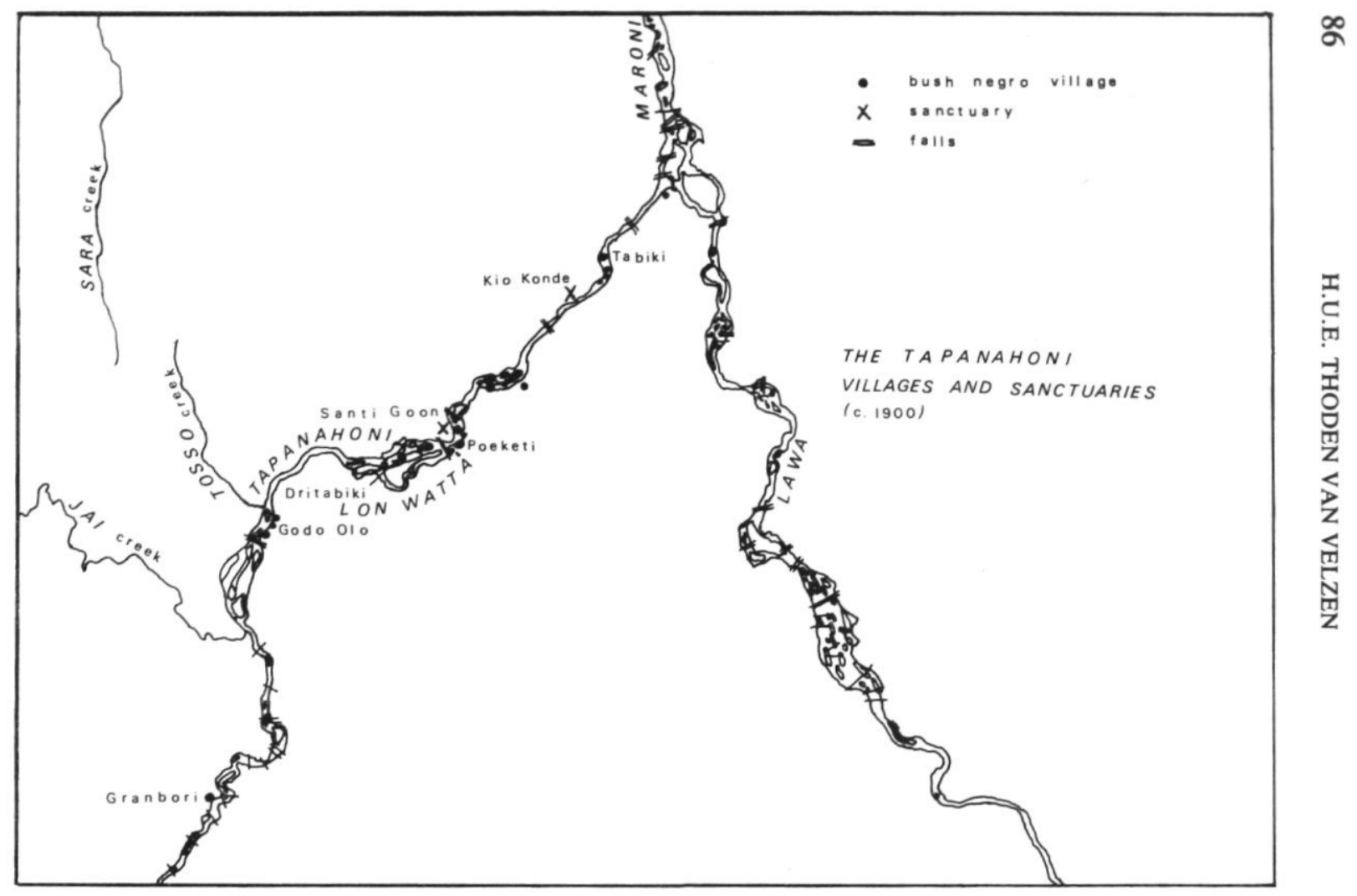

Fig. 2. The Tapanahoni villages and sanctuaries (c. 1900).

Downloaded from Brill.comఠ4/26/2023 06:29:38AM

via free access 
'plebeians', 'progressives' and 'conservatives' and, although these distinctions are somewhat artificial, behind his tour de force is the desire to treat Bush Negro society seriously. The book is a goldmine for Djuka history, crammed with historical details, but cast in a mould that reflected the position of one of the contending factions, that of the paramount chief Oseisie (1884-1915). Here is Van Lier's version.

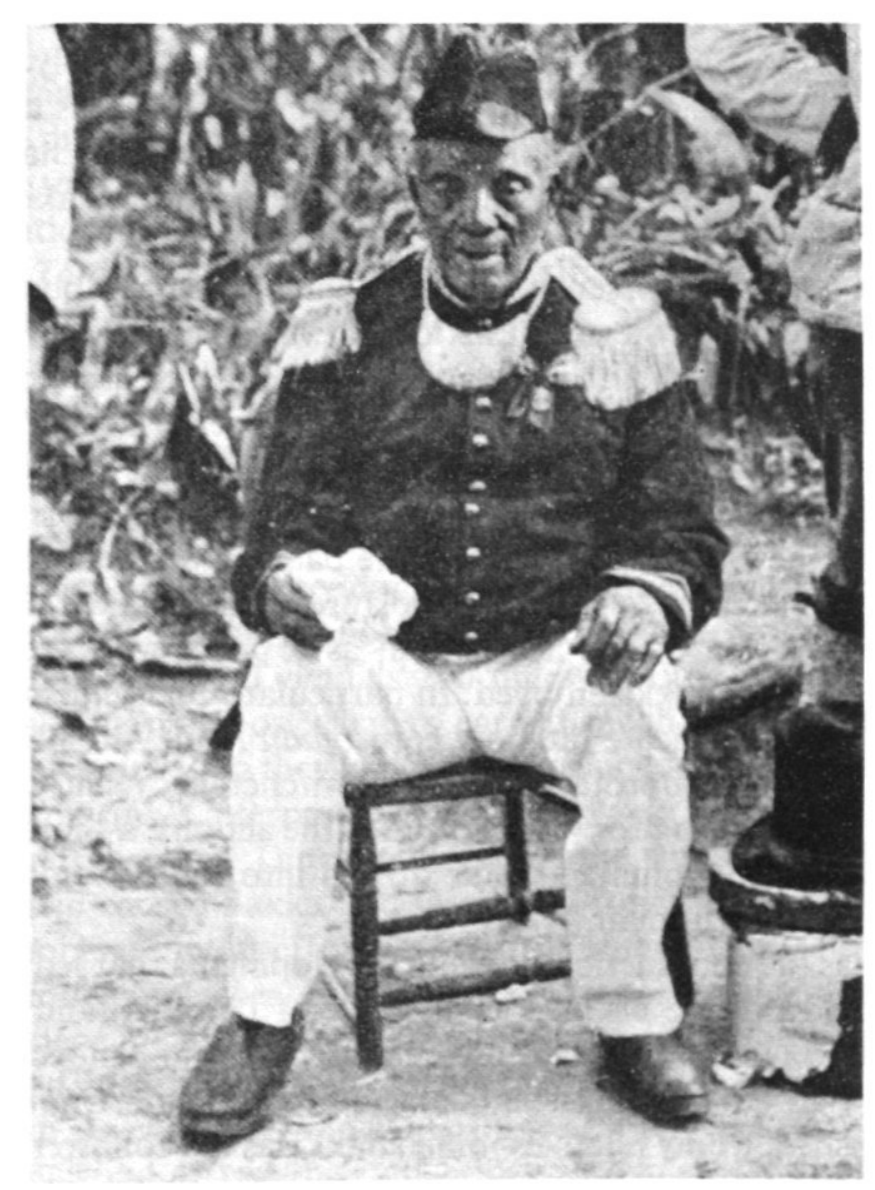

Fig. 3. Da Labi Agumasakka ('Sakka') in 1904. From: Franssen Herderschee (1905: 927). 
In 1882, the old paramount chief (Gaanman) of the Djuka, Blijmoffo, died. The tribal council of village headmen and other influential elders picked Oseisie for the succession, passing over his maternal uncle Da Labi Agumasakka (or 'Sakka' as he was regularly called) who had coveted the position for years. Leadership relations were considerably complicated by the circumstance that Sakka was custodian of the Gaan Gadu shrines and had the benefit of years of training in the ritual and the sacred lore of the cult. For Van Lier, Gaan Gadu or Gaan Tata was an old tribal cult dating back to the war of independence. Whoever commanded at its holy places could, by virtue of this fact, claim to be recognized as a tribal leader. That Oseisie was promoted over his head was hard for Sakka to swallow and he had no intention of forsaking his other prerogatives.

The situation worsened when the Dutch began to pursue an active interest in the southeast corner of Surinam where gold had been found. With the need for Djuka Bush Negro labour in mind, they courted Oseisie. In 1891, Oseisie's salary was boosted from fl. 150 per annum to fl. 1,000 and he received favours and personal assurances of sympathy and support. Once Oseisie knew he could count on the backing of the Dutch, he assumed a more aggressive posture with Sakka. Oseisie demanded that Sakka accept him as a priest with the same privileges that Sakka enjoyed. In particular, Oseisie demanded the right to fabricate the holy cord (gadu tetei), the principal amulet providing protection against witchcraft. What Oseisie, in fact, was asking for was 'a piece of the action', a share in the considerable emoluments that flowed into the coffers of the Gaan Gadu custodian.

It was the conjunction of these developments that led Sakka to decide to leave his ancestral village of Dritabiki and found Granbori (1891), two days upstream by dug-out canoe. It was here that the new headquarters for Gaan Gadu was established. Many relatives joined Sakka as did followers from many other Djuka villages.

For about a decade Oseisie resigned himself to playing second fiddle to Sakka. Then he struck back by fabricating his 
own Gaan Gadu shrine and oracle. Eventually Sakka choose to accept that situation and in September $1903^{8}$ a great feast of reconciliation was held at Dritabiki. Thereafter, with friction but never an open schism, two Popes ruled the Gaan Gadu cult: Sakka at Granbori and Oseisie at Dritabiki. After 1915, when both men died, the two oracles of Gaan Gadu continued their independent existence.

\section{The revolutionary break theory}

In his manuscript Boschnegeriana, Morssink (1934) expounds a quite different view, although he starts his argument in a way similar to Van Lier. Oseisie waited until some time after his inauguration in 1888 before laying claim to the Gaan Gadu or Gaan Tata priesthood. A delicate rift had always existed between Oseisie and Sakka which now appeared to deepen dangerously. Then, just in time, a sudden unexpected windfall prevented outright war between the two men. In the $1880 \mathrm{~s}$, gold had been found in the interior and thousands of treasure hunters were lured to penetrate ever deeper ir. $心$ the interior. For the Bush Negroes, the gold industry brougnt with it the sudden expansion of economic opportunities. Bush Negroes manned the dug-out canoes that carried the gold-diggers, their equipment and victuals 200 miles into the jungle to the placers. The transport carriers earned much more money in their new trade than they had formerly gained in lumber work.

In Morssink's interpretation, the newly earned hundreds of French francs and Dutch guilders in the hands of younger tribesmen caused Sakka and Oseisie to forget their squabbles and cooperate in an effort to skim off some of the money of these nouveaux riches. But, they needed a powerful bait to lure the independent boatmen to Dritabiki, somewhat off the travelled Maroni-Lawa river routes used by the gold-diggers. The two shrewd men - in Morssink's account - turned to an obia that had served their ancestors well in the 18th century war of independence by helping them find their way through the jungle and by directing their fighting. Oseisie and Sakka 
knew that the wealthy boatmen dreaded the witches, less fortunate neighbours and kinsmen who, envious of their riches, were prepared to commit heinous crimes for getting their share. Sakka and Oseisie dug up the old Gaan Gadu war obia, buried at the holy place of Santi Goon, and brought a part of it back triumphantly to Dritabiki. The boatmen were guaranteed that this obia would give them protection against the witches as nothing else could. The plan worked. The transport carriers flocked to the Gaan Gadu shrine at Dritabiki, and Sakka and Oseisie lined their pockets with the handsome fees that grateful boat owners brought them. To Morssink's mind, this was the way in which the older men continued to exploit their sons and younger relatives.

Some years later, the two men fell out again, this time over the division of spoils. In anger, Sakka left Dritabiki to found Granbori and he took the Gaan Gadu obia with him. Oseisie found himself on the ruins of his former estate. He realized he was deprived of a good part of his income, without the prestige that is conferred on the custodian of a great obia and without the power to manipulate public opinion with oracular verdicts. Oseisie returned to the holy place of Santi Goon, dug up the old obia and, as Sakka had done before him, fabricated his own holy bundle by placing a small part of the old war obia in it. For a few years both shrines competed for the favours of the faithful. But ill health brought Oseisie to heel and in his despondency he realized there was only one great medicineman to turn to: Sakka. With the latter's help Oseisie recovered and good relationships were restored. A time of respectful coexistence ensued, bolstered up with price agreements for the main amulets sold and services rendered.

Some of Morssink's gibes are quite unpalatable, as when he harps on the theme of shrewd old men scheming to keep a hold over their many wives.9 Another drawback in Morssink's account is that he exaggerated the conscious manipulation of religious institutions on the part of both Sakka and Oseisie. Things were more complicated than that, as I hope to show. On the other hand, it should be pointed out that Morssink was the first to grasp the significance of the altering forces of pro- 
duction. In the 1880 s, within only a few years, the Djuka had given up lumbering for the much more lucrative business of transporting gold-diggers. Morssink rightly wished to understand changes in Djuka institutions by placing them against the backdrop of these alterations.

\section{The new Gaan Tata or Gaan Gadu cults}

Both the accounts of Van Lier and Morssink bring valuable points of view. There certainly was continuity, as suggested by Van Lier, in the sense that a Gaan Tata cult existed long before 1891. Its major shrine was at Dritabiki, while subsidiary ones were situated in a few Saramaka villages on the Pikin Rio and Gaan Rio rivers and probably also at Sophieboeka or Dombikondre on the Suriname river. ${ }^{10}$ However, the Gaan Tata cult of the Djuka and Saramaka was not identical with the movement that spread so rapidly through Surinam's interior in 1891, although the latter one was also known as the Gaan Tata cult. The old Gaan Tata cult simply was absorbed into the new movement, as happened to a few other Djuka cults. The Gaan Tata or Gaan Gadu movement that emerged in the 1890s, contained radically new features and these were visible to contemporaries. A few opinions from people who lived in these times and were well acquainted with Bush Negro religious life follow.

Kersten, a missionary who spent some years at Albina, and was in daily contact with Bush Negroes, made a trip to Dritabiki in 1895. 'Seven or eight years ago', he (1896: 185) wrote, 'Oseisie had instituted the Gaan Tata movement at the prompting of Sakka'. Buck, another missionary of the Congregation of Moravian Brethren, who was stationed on the Cottica river from 1892 until 1895, wrote in a similar vein (1896: 67): 'The supreme God who makes decisions about everything is Gaan Tata. But his power is of recent date. Formerly, the God Sweli ruled the Djuka people'.

Of particular importance is the testimony of the Matawai Bush Negro Johannes King, a prophet and visionary who 


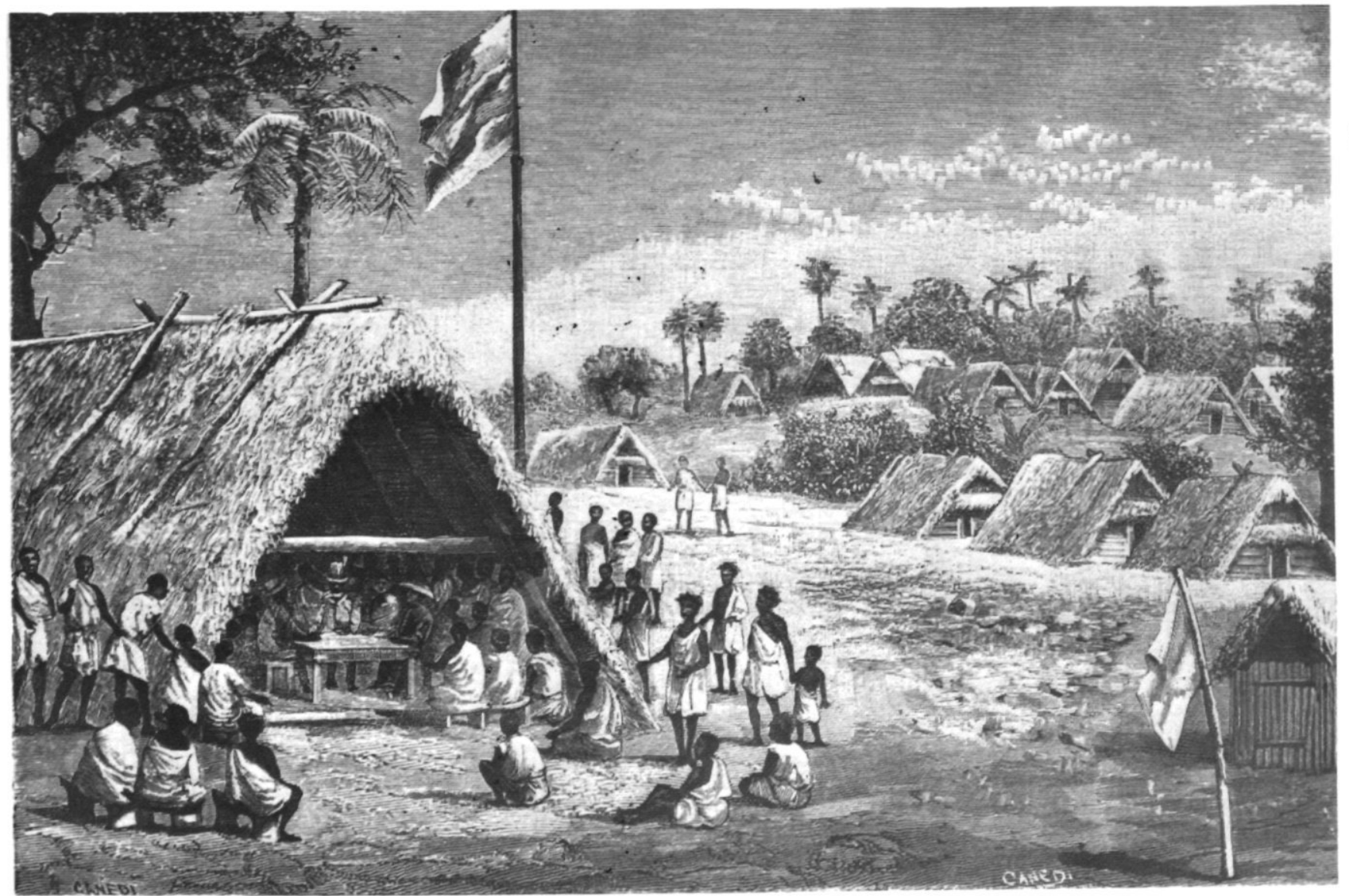

Fig. 4. Poeketi in 1886. From: Brunetti (1890). 
brought the Matawai into the Christian fold. King knew the Djuka quite well; his father was a Djuka and Johannes King had visited with his father's relatives on the Tapanahoni in 1865. King maintained contact with Djuka settlers on the lower Saramacca and other coastal areas. During 1893 and 1894, he frequently referred in his diaries to 'this false and new God Gaan Tata' (De Ziel 1973: 121-122).

Those Djuka who actually lived on the Tapanahoni at the turn of the century were quite convinced that this cult was something new, as we know from the diaries of the teacher Spalburg (1896-1900) who had his residence at Dritabiki during the last years of the preceding century. One entry in his diary is particularly interesting. In June 1898, thousands of birds swarmed over the unharvested rice fields of the Djuka. A few men explained to Spalburg that the swarms of birds visiting them was punishment for Sakka's sins, who had dared to substitute the worship of the Spirit for the old, time-honoured ancestor worship.

A new movement thus, known under many names: Gaan Tata, Gaan Gadu, Gaan Obia. To distinguish it from its predecessors it will hereafter be called the Gaan Gadu cult. We should now turn to some new material from archives and oral history to reconstruct the beginnings of the new cult.

\section{Sakka controls the obia}

A digression on the concept of obia is now in order. According to the Djuka, enormous powers dwell in the universe, most of these untapped by and in fact even unknown to men. An obia is that part of these forces that has become available to mankind, is beneficial to human beings and has assumed a definite shape so that it can be distinguished from other such supernatural forces. An obia may choose any sort of vessel; an amulet, a bundle and even an human being. The medicines of the Europeans are also called obia. What sets an obia apart from other supernatural forces is the beneficial influence it manifests, with healing of body and soul as the ultimate criterium. 
The control by humans over obia varies considerably. On the one hand, there is the ordinary amulet that brings its blessing almost automatically, though this is contingent upon the observance of a few rules such as not eating the meat of certain animals. On the other hand there are those obia that have to be worked and fought for. Their power can only be briefly harnessed by adhering strictly to all rules and prescriptions, performing the required libations and avoiding to give any displeasure to the obia. Quite often, harmonious relations among relatives are a necessary condition for the proper functioning of the obia.

Three obia were particularly relevant to Djuka society in the 1880s. First, there was the Sweli obia, a supernatural force residing in a small bundle kept in a shrine at Dritabiki. Humans could come into contact with this obia by drinking its sacred potion (diingi sweli) while swearing an oath. In 1760, when Dutch emissaries came to negotiate peace with the Djuka, they concluded their talks by drinking a potion in which a few drops of blood from each of the negotiators were mingled (Hartsinck 1770: 800). They were drinking the Sweli obia. In the 19th century, Dutch officials and even businessmen who had come to conclude treaties or agreements with the Djuka also had to take the blood oath; while swearing to uphold the conditions of the agreement they drank the potion (Coster 1866: 3-4). All Djuka adults, males and females, were obliged to take this oath. One could only become a true and respected member of the tribal community by taking part in the ritual. Allegiance was sworn to the Djuka nation and to one's fellow tribesman (cf. Lenoir 1974).

In later times, the oath came to be interpreted more and more as an ordeal. Those who had perpetrated acts of witchcraft would be killed; those who were innocent could expect protection against the witches by an infusion of power (kaakiti) coming from the sacred potion. At the end of the 19th century, the oath taking was delegated to the leaders of matrilineal kin groups and village headmen and was to be renewed every three or four years. Additionally, those who had come 
under suspicion of witchcraft would either come voluntarily to Dritabiki to cleanse their reputations or could be called to appear for the undergoing of the ordeal. Control over this obia was vested in the elders of Dritabiki's main lineages: the Black lineage of the Oto clan and two lineages of the Misidjan clan. Among the small group of elders who could administer the oath, Sakka was undoubtedly primus inter pares.

From their control of the Sweli obia the custodians derived considerable power. It was their privilege and duty to interpret signs of malady in the oath takers for approximately a week after the ritual. If they decided that symptoms of minor physical distress were revealing Sweli's punishment for transgression of his holy laws, they could then cleanse the patient by subjecting him to additional ritual for which fees would be exacted. If, however, the patient suffered agonies and died within a week, this was interpreted as a punishment for witchcraft. The corpse would be brought to a creek near Santi Goon and thrown into the undergrowth. No rites, wailing or other signs of grief were allowed for such cases. The possessions of these persons were confiscated, with part of it left at Sweli's shrine at Santi Goon, part of it returned to the relatives, while a considerable portion of it was kept by Sweli's priests as a compensation for their work.

There was also an extra source of power attached to Sweli. In the shrine a small bundle was stored containing hair and nail parings of dignitaries who had served Sweli in the past. The bundle could be interpreted as any ordinary 'carry oracle', a technique to be discussed later. This was a way to consult $S$ weli indirectly because the ghosts of this prominent group of ancestors were considered to be in contact with Sweli in the hereafter. The consultation of the oracle was always done in the seclusion of the Sweli shrine with only a handful of priests present. The oracle was believed to be particularly relevant to all living priests of the Sweli cult and their closest relatives and as such usually was not consulted for matters pertaining to other people. 


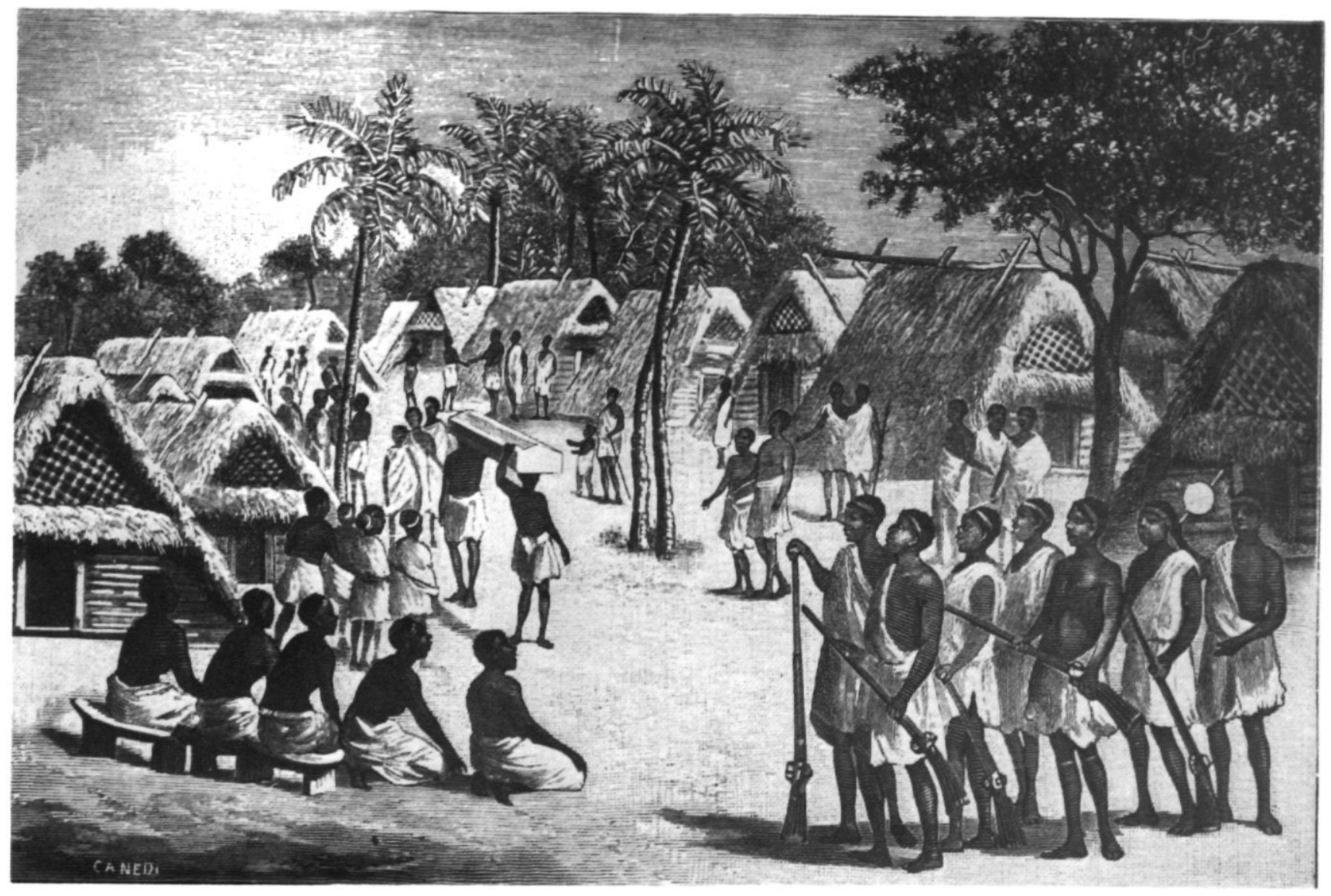

Fig. 5. The 'carrying of the corpse' in a Tapanahoni village. From: Brunetti (1890). 
The second obia of tribal significance was Gaan Tata or Gwangwella. At the end of the nineteenth century it had come to be considered as the most prominent of the war obia (feti obia or piiti busi obia); a secret weapon that had split the bush open for the Djuka warriors as the Red Sea had been opened for the people of Israel. The obia had advised the ancestors on military tractics during war days and had shown them the way to the Tapanahoni. After the peace treaty (1760), the elders of the Oto clan decided to bury it at Santi Goon, a sanctuary in the bush opposite the village of Poeketi, and close to the site where the corpses of witches were abandoned. The obia was believed to be too powerful to be employed under peacetime conditions, but the real reason may have been the growing friction between the two lineages that form the Oto clan: the Red and the Black lineage. The Red lineage was apprehensive of domination by the Black one and therefore demanded that the obia be dismantled. The compromise that was finally reached included its burial and a compensation for the owners, the Black lineage. Some objects holding the diluted power of Gaan Tata such as materials adequate for the diagnosis and treatment of sickness were to be placed at the disposal of the elders of the Black lineage. The diluted or 'derived' obia was called the Big Calabash (Gaan Kabassi) after the calabash in which these sacred objects were stored.

The Gaan Tata, as he manifested himself in the Big Calabash, functioned as an oracle. The priest or priestess in charge could consult it in various ways. After a ritual bath had been made with herbs associated with the godhead, the officiating priest would wash his hands in it. Then, for a short period, one could ask the priest questions. The movements of his hands would indicate the answers. Or, with a somewhat different technique, the Big Calabash was held in the hands of the priest; as soon as his hands began shaking the Gaan Tata obia was active and questions could be asked. This tactile consultation of the obia is indicated by reference to it as a 'feel feel obia' or divination obia (fii fii obia).

Control of this obia was firmly in the hands of Sakka. Other elders might assist him, but always at his instructions. Sakka's 
foster mother, Ma Djemba, an Oto woman who had been high priestess of the Gaan Tata cult for most of the second part of the 19th century, had trained him in the sacred lore and ritual of Gaan Tata. She had died before 1890, when the events which I will soon relate, began to unfold.

Finally, there was a third obia that was part of the ritual complex Sakka inherited. Formerly, the Djuka had been afflicted with a high incidence of infant mortality. Paanga Booko, a member of the Misidjan clan who happened to be married to Ma Djemba, Sakka's foster mother, decided to save the Djuka people from extinction. In one version, he travelled to the plantations where he bought the obia from the slaves; in another, he was already in the possession of the obia but rendered the Djuka a service by placing it at their collective disposal. The results were astounding. The Agumaga obia, as it was called, successfully combatted infant mortality. In gratitude,

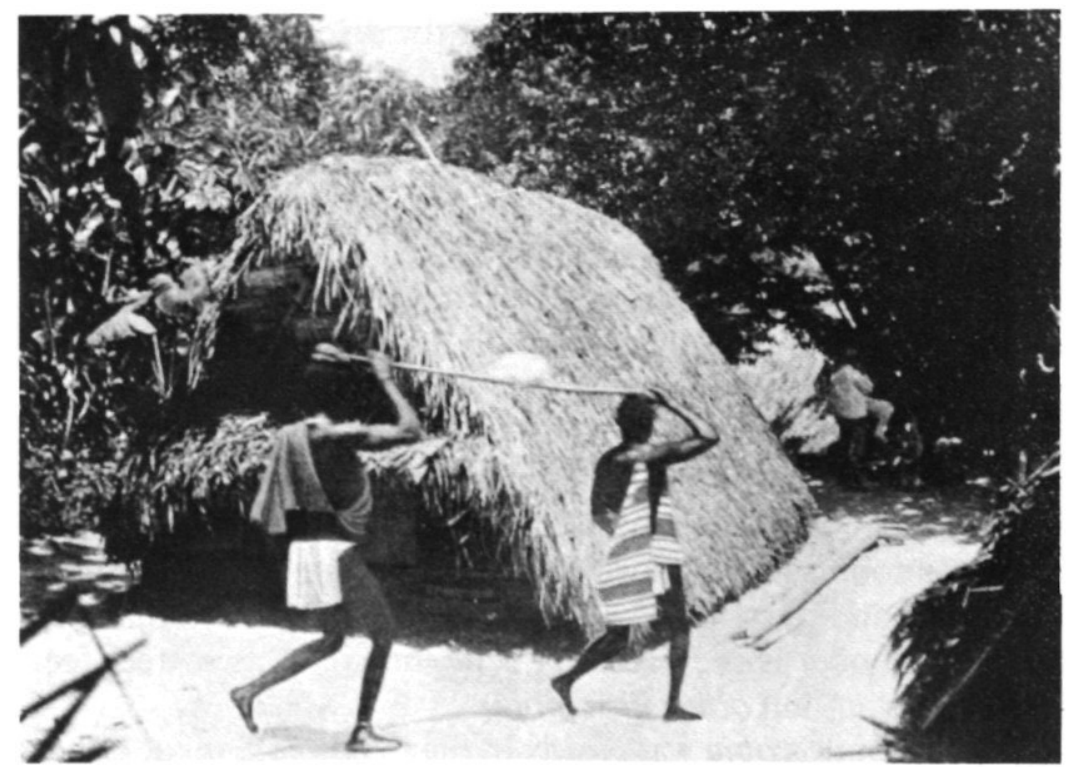

Fig. 6. The 'carry oracle' of Gaan Gadu at Dritabiki in 1907. From: De Goeje (1908). 
the great council of 'the twelve clans of Djuka' (den twalafu) another name for the Djuka nation - resolved that Paanga Booko was to be richly rewarded. In the future, he would share in the bounty of the Sweli priests by receiving part of the legacies of those killed by the Sweli ordeal. This was not, informants are quick to add, on a par with the enormous volume of goods that flowed to the hieratic establishment in the 20th century, but yet it was regarded a handsome present (wan kadoo).

Ma Djemba became jealous of her husband's prosperity. By devious means, she tried to seduce the obia to reveal its secrets to her. She was not successful. However, Ma Djemba was quick to avail herself of another opportunity when it presented itself. Paanga Booko, who was in the habit of talking in his sleep, began to divulge information about the contested obia in this involuntary way. Ma Djemba carefully memorized everything she heard about the taboos connected with the obia, about its preferences and about its operating procedures. When she was through learning, she informed her husband. He was furious. The quarrel grew until Paanga Booko had recourse to a drastic measure to settle it; they would take a blood oath together. This was not to be Sweli, the tribal one, but something more ordinary and yet dangerous. Paanga Booko and Djemba died on the same day they took the oath, killed by the gods because they had acted irresponsibly and courted danger. Their bodies were left at Santi Goon. However, before her death Djemba had already intimated the secrets to her foster child, Sakka.

Among the descendants of Sakka a more friendly version of the obia's transference is current. In his old age, Paanga Booko felt neglected by his relatives and, with the exception of his wife and Sakka, no one seemed to care for him. When Paanga Booko was dying, Djemba advised Sakka to beg the old men to pass the obia and its secrets on to him. This Sakka proceeded to do and that is why the Agumaga obia became his. In brief, by the end of the nineteenth century Sakka had gained control over two obia (Gaan Tata and Agumaga) and had secured an important position among the Sweli priests. 


\section{The return of Oseisie}

In 1882 the paramount chief Blijmoffo died. After the burial rites had been properly executed, the Great Council (gaan kuutu) convened. It was composed of all village headmen and also of prominent elders of the Oto clan, the clan of the deceased. Its task was to choose a successor from among the male adults in the Black lineage of the Oto clan. Sakka was an obvious candidate for succession to this high office, but he was passed over in favour of his younger nephew Oseisie. This might have been expected. The Great Council usually attempted to divide the offices of high priest of the Gaan Tata cult and that of paramount chief (gaanman) over two persons. Other villages stood to gain from a division of powers at Dritabiki. A combination of power assets in the hands of one person, on the other hand, could jeopardize the autonomy of villages and the democratic relationships within their councils.

A delegation was sent to the Cottica river where Oseisie had settled with a few relatives in a lumber camp. Oseisie refused, protesting that he was too young and not fit to accept such a high office; why not ask others? Perhaps this also had been expected, as the successor to an office should drag his feet, showing respect for his predecessor and humility to all and sundry (Köbben 1967: 28). But Oseisie seemed to overdo it; during 1883 two delegations were sent on their long trip to the Cottica and he still refused to accept the office. Moreover, he was hiding behind pragmatic reasons for not being able to return: there were not enough boats sent to carry him, his relatives and their belongings, or he would insist he had to square off logs before they could be sold to Paramaribo. These apologies were interpreted by everyone as signs of apprehension for his rival on the Tapanahoni river, and this message settled the leadership of the third expedition.

Today it is still remembered among his relatives that Sakka took every precaution to make this third expedition, now under his leadership, a success. A great number of boats was brought together so that Oseisie's whole following could be transported in one trip to the Tapanahoni. They allowed 
Oseisie, accompanied by Sakka, to go shopping in Paramaribo, and they provided him with assistants to help him finish the squaring of logs, and to guard him as well so that Oseisie would not be able to withdraw from the honorific occasion. Oseisie's disappearance would entail 'loss of face' for Sakka; people would accuse him of not really wanting the expedition to succeed so that he could usurp the position for himself. Moreover, an eventual fourth expedition under the leadership of another notable would definitely be successful. Sakka had no choice but to bring Oseisie back to the Tapanahoni. In any case Sakka was confident that the controller of the obia would be the de facto leader of the Djuka people. After completing their shopping the two men returned to the Tapanahoni early in 1884. Oseisie had to wait until 1888 before he could finally be inaugurated by the Dutch colonial administration. Brunetti (1890: 235-239), who met with Oseisie in Poeketi in 1886 was impressed by the role Oseisie's uncle played. Brunetti was convinced that Sakka, ${ }^{11}$ 'an intelligent and crafty man', had great influence over Oseisie. These observations tally with the accounts that Van Lier and Morssink give of the early years of Oseisie's chieftainship. Beginning with the following section, 'The Death of Coba', this paper will chiefly look to oral sources for an answer to the questions concerning the first days of the Gaan Gadu cult. It will be based on eye-witness accounts of a generation that lived through these turbulent days, and then passed their experience on to their children. These children are now old men and women. ${ }^{12}$

\section{The death of Coba}

Sa (sister) Coba, a young woman of the Red lineage of the Oto clan, died at Poeketi in 1889 or $1890 .{ }^{13}$ Apart from the fact that she had never given birth to children, nothing is remembered about her today. As was the case with every adult who died, her ghost had to be subjected to an interrogation to learn the causes of her death and to obtain information on any supernatural danger the ghost might know about. The core of 
this inquest was the ancient West African tradition of 'carrying the corpse' (Rattray 1927: 167-174), a ritual maintained by Surinam's Bush Negroes. Among the Tapanahoni Djuka, the inquest was obligatory for every deceased adult until a new prophetic movement abolished it as a corrupt practice in 1972 (Thoden van Velzen \& van Wetering 1975).

Before returning to the interrogation of Sa Coba's ghost, we need to discuss this 'carrying of the corpse' and the association of gravediggers who performed this ritual.

The corpse was tied to a litter and carried on the heads of two bearers through the village. The ghost communicated through the bearers' movements. A forward move signified an affirmative, a backward or sideways one usually meant a negative answer. Wild, chaotic movements of the litter revealed the ghost's discomfort and embarassment at a certain line of questioning. The interrogation of the deceased's ghost took place at some distance from the gathering in the centre of the village. The ritual was mainly conducted by the association of gravediggers who would usually invite one or more village headmen and several elders from the lineage of the deceased to participate in the questioning and also in the drawing up of a communique for the bereaved and the Djuka nation.

About the gravediggers. During adolescence Djuka men had to make a choice between two associations: they could either join the gravediggers (oloman) or become a coffin-maker (kisiman). The task of the last association was limited to what the name suggests. The coffin-makers had no work to do if the deceased was found out to be a witch as these nefarious persons were not entitled to a coffin; as indicated above their corpses were left unburied at reserved spots in the jungle. Thus, the coffin-makers convened only after the inquest had proved the deceased to have been a respectable person. While making a coffin, gravediggers and coffin-makers indulged in horseplay at each other's expense and in sham attacks; moreover, they attempted to get as large as possible a share from the communal meal at the end of a day's work.

The gravediggers had many more responsibilities. They attended to the interment of the deceased and took charge of the rites for the dead. From their ranks, they selected the bearers of the corpse and the interrogators of the ghost. Following a death gravediggers, from the village where it occurred as well as neighbouring villages, gathered. Even gravediggers from faraway places who happened to be visiting or passing through were expected to participate and they would do so on an equal footing. Ritual started within a couple of hours after a demise. Usually, there would be two phases of carrying the corpse. Relatives of the deceased were invited to share in the tasks of carrying and interrogating. In this way, later charges of fraud were preempted by letting the relatives share in the responsibility of the verdict.

On the surface, relationships within the association of gravediggers seemed strongly egalitarian. A closer inspection revealed that some members held key positions. These leaders, or bosses (basi) as they were called, assisted by a few elders selected from the relatives of the deceased, formed the committee that supervised the inquest. This same group was also responsible for the decisive communique issued after the carrying of the corpse. 
Although nothing foreshadowed the dramatic occurrences of the months following Coba's death, from the very first day something seemed to go awry. Two hours after her death, while gravediggers and headmen from neighbouring village were arriving, the corpse was wrapped in a cloth and tied to a makeshift litter. It was lifted and placed on the heads of the bearers. They stood motionless while a libation was made to the ancestors solliciting help. The first question was posed to Coba's ghost. 'The chief (gaanman) was missing some of his subjects; would the deceased help him find these persons?' At the request of the gravediggers, some villagers were now playing the traditional game of hide-and-seek and secreted themselves in a deserted house. After some inconclusive movements, the ghost replied that it deeply regretted not being in a position to comply, not even to the wishes of the chief. This was generally interpreted as an admission on the deceased's part that she had perpetrated crimes of witchcraft.

A second team of bearers was called upon. A verdict of witchcraft was the strongest condemnation possible; it would be a stain on the blazon of the relatives and such a verdict could only be given after some form of endorsement from the relatives had been secured. Although this is not recalled today, it is highly likely that at least one relative of the deceased had acted as a bearer. The second team did not waste time; it headed straight for the boat landing where it was stopped by the gravediggers. Now, the verdict could no longer be postponed. The ghost of the deceased had almost forced the bearers into the river, a definite and clear answer to the questions of gravediggers and elders. Decidedly, the deceased was ashamed to stay even one minute longer in the village. She felt she had no right to remain among the respectable people she had sought to hurt.

Although most people present properly understood what had happened, the burial committee of elders and gravediggers did not issue an immediate communiqué, but instead sent a message to chief Oseisie at Dritabiki explaining what Coba's ghost had revealed. The message of the ghost (dede moffo) was traditional, as was Oseisie's: 'Let things happen as the ghost of 
the deceased prefers them to happen; we are washing our hands of it; it is the ghost of the deceased that has the last word'. By the time the messenger had travelled to Dritabiki and back, it was late in the afternoon and too late for the gravediggers to carry Coba to the banks of that unholy creek where the corpses of witches were discarded. It was decided to let the corpse rest for one more night at Poeketi. This, and the outcome of the inquest, were then communicated to the gathering.

This posthumous condemnation shocked the gathering at Poeketi. Nowadays, Coba is recalled as 'the first witch of the Djuka'. This is a distortion of 19th century history because there were witch trials and condemnations before 1890 and instances have been recorded of Djuka who were burnt at the stake (Hostmann 1850: 277; Freytag 1927: 12; De Groot 1977: 36, 52). Coba may have been the first one to be condemned after her death, but this seems equally unlikely. She is probably remembered as 'the first witch' because of the deep impression left by the interrogation and subsequent events. Moreover, there is reason to believe that Coba's death ushered in a new era, in which there were many more posthumous witch trials, accusations and condemnations.

The following stage in the interrogation of Coba's ghost began in a very routine way. On the morrow, the corpse was lifted and placed on the heads of two gravediggers for a last interrogation focusing on instruments she might have used for her malevolent work. The ghost did indicate these; everywhere bottles were dug up and strange objects removed from between the palm leaves covering the huts. This was a fairly routine occurrence until 1972 and the objects thus recovered usually were buried or hidden in these places by people as weapons of defence against the black magic of their neighbours and kinsmen. But then, shortly before the corpse would finally be carried away from the village, a new and unexpected thing happened. 
Coba reveals a conspiracy

Instead of remaining close to the ritual centre of the village where the interrogation of a ghost takes place, the bearers broke through the circle of gravediggers, elders and relatives and ran for the bush. They were stopped at the edge of the forest by gravediggers who had hurried to intercept the bearers. There, Coba's spirit revealed that she had been only one out of an enormous coven represented in every village on the Tapanahoni. Coba's ghost added that she felt so ashamed of what she had done that she offered the Djuka people to betray all the other witches so that the coven could be liquidated. When we strip the incident of its supernatural rhetorics, what remains is a statement by the gravediggers to the Djuka saying: 'Our work has not been completed with this single disclosure; we demand a full investigation of the Djuka nation and we, gravediggers and elders at Poeketi, are the ones to conduct that investigation'. Courage was needed to adopt such a position; they were clearly deviating from established procedures by taking this bold initiative. The reputation of a gravedigger was vulnerable; on the one hand he was protected by the belief that gravediggers were mere instruments moving as the ghost of the deceased ordered them to do, while on the other people were suspicious that the bearers would attempt to distort the ghost's movements for personal gain. In this case, the bearers were running the risk to be denounced as frauds, not because their tribesmen did not share their apprehension, but rather because a high-handed course of action would arouse suspicion of political scheming.

Now that the investigations began to gather momentum, an end could not easily be put to them. A fresh team of bearers, called to replace the first one, confirmed the findings; Sa Coba promised again to reveal the conspiracy everybody had suspected to exist. Popular excitement was great and although permission for this unusual extra interrogation - never again resorted to - had to be obtained from chief Oseisie, no one doubted the outcome. This, after all, was what everybody had been waiting for. 
In a special palaver at Dritabiki, Oseisie end Sakka granted permission. The seal of the latter, custodian of three important obia, was as essential as that of Oseisie. Whatever misgivings the two most powerful men of the Tapanahoni region might have had against this development, there was nothing they dared do to thwart it. A refusal would arouse the ire of the people. Besides, this was the second day and no one at that point could have predicted that the investigation would continue for months and leave no village untouched by its findings. So, on the second day, it was quite understandable that the palaver at Dritabiki would grant permission for a sequel to the inquest.

Poeketi, the place where this inquest was to continue, was not an ordinary village. Up till approximately 1840 it had been the residence of the Djuka chiefs. The old tribal shrines were situlated there and even today tribal rites cannot be complated without prayers and libations at these sacred places. Moreover, Coba was a woman from the small but prestigious Oto clan which consisted of two lineages: the Black lineage resident at Dritabiki, the Red lineage located at Poeketi. Any demise of a member of the Red lineage would therefore involve notables from Dritabiki. Finally, Poeketi was strategically situated. It belonged to a cluster of villages that straddled $O p u$ (upstream) and Bilo (downstream) territory. Although the significance of this distinction between 'upstream' and 'downstream' Djuka has often been overrated in the literature, nonetheless it sometimes played its part in conflicts. Poeketi, lying at the beginning of $O p u$ territory, could recruit elders and gravediggers from both areas. All in all, the geographical position of Poeketi and its political status added to the rapid spread of the movement over the Tapanahoni valley.

Once the interrogation was resumed the importance of the inquest became clearer with every day that passed. The ad hoc committee of elders and gravediggers that supervised the interrogation of Coba's ghost on the first and second day was expanded; notables from Dritabiki and other villages joined it 
and transformed it into a 'permanent commission of enquiry' (hereafter to be called the Investigation Committee). It was ordained that all adults of Poeketi, males and females, and all members of the Red lineage who had taken up residence elsewhere, had to pass under the bier that held Coba's corpse. Those who were innocent could pass freely, those who were barred passage by sudden movements of the bearers were either witches or guilty of other hostile deeds against their fellow tribesmen. The witches, and perhaps also other 'criminals', were expected to undergo a cleansing ritual for which they had to pay. People from neighbouring villages, who had come to the investigation attracted by sensational revelations could, 'if their heart urged them to do so,' submit to the screening as well.

While the subjection of Poeketi's inhabitants and of other 'volunteers' to the witchcraft screening was not unusual, some developments certainly were. They all occurred after Sakka had left Dritabiki to pass a few weeks in his rustic bush camp, two days paddling upstream from Dritabiki. Sakka, and other elders of Dritabiki as well, did so periodically. They enjoyed staying for a while in the quiet and secure ambiance of their bush camps, with only the 'children' (dependents) around and with fish and game more plentiful than around Dritabiki which was part of a cluster of about ten villages (Lon Watta). As far as can be reconstructed today, it was no political manoeuvre on Sakka's part to withdraw for a few weeks to his bush camp. All the accounts stress that Sakka, once he understood what was going on at Poeketi in his absence, felt that the Investigation Committee had deliberately sprung an unpleasant surprise on him.

After Sakka left for his bush camp, the following drastic developments occurred. First, the witchcraft screening was made obligatory for all Djuka of the Tapanahoni valley, from Poligoedoe at its mouth up to the farthest bush camp on the upper reaches of the river. All had to pass under the bier in order that Coba's ghost might indicate her former accomplices. That this ordeal had become obligatory meant that permission of chief Oseisie had been secured. With 
hundreds of Djuka now streaming into Poeketi and with new denouncements of witches everyday, the whole of the Tapanahoni was in turmoil. Secondly, as the weeks passed by, the supernatural process was redefined. The decomposing body did not harbour only Coba's ghost: it had also become an instrument in the hands of Sweli, who had 'mounted' Coba (Sweli subi Sa Coba). ${ }^{14}$ Such a 'definition of the situation' could only mean that Sakka's colleagues of the Sweli cult considered the enquiry at Poeketi as a legitimate search for witches from which they could no longer stand aloof. Finally, the witches discovered by the interrogation were ritually cleansed and then restored as honourable citizens to the nation by yet another ritual. Who the priests were who performed these rites is not known to my informants; yet, it seems likely that these were the Sweli priests, the only ones who had an anti-witchcraft 'apparatus' at their command.

Obligatory screening of all Djuka, cleansing rites and fines for those who were found out as witches - this clearly was an anti-witchcraft movement. It soon began to branch out in other directions as well. After weeks of interrogations, the Investigation Committee decreed that Sa Coba's ghost with the assistance of Sweli, would remove most spirits that possessed humans. It was felt that too much harm had already been done by mediums employing such spirits for their own, selfish purposes, often endangering the health of their kith and kin. This, it was announced, would have to come to an end. All spirit mediums and all custodians of spirit shrines would have to subject themselves to the judgement of Coba cum Sweli.

After the massive screening of witches, this was the most drastic step taken. A medium considered his spirit as property, something which had been dearly paid for in time and money. An exorcism would mean the undoing of years of instruction and a great financial loss. It also implied giving up any hope of influencing village affairs in the future through mediumship. For the custodian of a spirit shrine, even bigger losses were involved; no more supplicants or apprentices paying fees, no more influence through control of divination.

In less than two months, hundreds of mediums were 
deprived of their spirits. All supernatural beings who were potentially harmful, or were believed to be indifferent to the human lot, were immediately exorcised. The sole exception was the group of mediums with Kumanti spirits - the most benign of all supernatural beings after Gaan Tata and Sweli. The general effect was, as one informant recalled his mother describing the consequences: 'a complete nocturnal silence, only the river was heard at night, everything else was so quiet! The barking and howling of mediums in their nightly trances had disappeared from the village scene. It was an uncanny, eerie silence. But five, perhaps seven years later, the spirits were all back.' ${ }^{15}$

\begin{abstract}
Ma Amalesi of Dritabiki is a case in point. She was ordered to appear before Coba's oracle at Poeketi. After she had passed under Coba's corpse the Investigation Committee concluded, from the movements of the bier, that she was not a witch but yet a threat to the body social as she was the medium of a bush spirit (Ampuku). A bush spirit has very little regard for the welfare of human beings and is well-nigh impossible to control by his medium. Hence, it was dangerous and it had to be excorcised. Ma Amalesi handed over all cult objects to the Committee. These, together with the sacred objects of dozens of other mediums, were burnt in fire. The spirit was exorcised with a simple ablution. A generation later, after Amalesi's death, her bush spirit took possession of Foida, her sister's daughter.
\end{abstract}

Rumour about these developments reached the missionaries in the coastal area. It gave them heart and they cheered the news that spirit shrines were burnt down or thrown into the river. However, they overestimated the iconoclastic drive in the movement; this was not an attempt to purify Bush Negro religion of lesser supernatural beings and leave only the High Gods Sweli and Gaan Tata. Kersten (1896: 185) who visited Dritabiki in 1895, was astounded when he saw spirit shrines and cult objects abounding. He asked chief Oseisie for clarification and received the reply: 'We have only done away with the really evil spirits; all the good ones we kept'. The missionaries turned sour on the Gaan Gadu movement when their hopes of a total destruction of 'idolatry' were frustrated. Nevertheless, the events at Poeketi were impressive by any standard; it was the most extensive iconoclastic and witchcrafteradication movement that ever swept through the interior. 
The power behind Coba's ghost

Poeketi in these days was the scene of a continuing carnival; hundreds of Djuka from all villages of the Tapanahoni were present everyday. Clad in their finest clothes, eager not to miss anything of the scandals unearthed and the excitement and sensation that every new day brought. Who was running this show, who was responsible for a run-of-the-mill inquest transformed into a witchcraft-eradication movement with strong iconoclastic overtones?

The obvious choice for consideration would be the gravediggers. They, after all, took the initiative. Were they more than a catalyst? It is doubtful. As usual, the gravediggers were nothing more than an ad hoc collection of individuals brought together from Poeketi and neighbouring villages to assume responsibility for this particular burial and the connected rites. Had the death occurred a month later, the composition of the group would have been different. The gravediggers did not form - it cannot be stressed enough - a corporate group with shared interests. They came from different villages and they were not expected to represent their local interests: 'Gravediggers have no village' (oloman n'áá konde) it was said. While this did not mean that they would not on occasion further the cause of their village, the ideology did work as a formidable check against any open attempt to promote the interests of their own group.

It is equally unlikely to look to the Investigation Committee as the body responsible for the happenings. This Committee was composed of gravediggers who held ranks of prestige (basi) in the association and notables from among the relatives and neighbouring villages. Analogous to the gravediggers, they were not supposed to speak for a lineage or even a village as their duty was to represent the Djuka nation and remain aloof from local squabbles and interests. Once the process was under way, they certainly must have attempted to give some guidance to it - the increase in size of the Committee with Sweli priests attests to that. Still, the primary force did not come from their ranks. All the evidence indicates that they 
were just as surprised as anybody else was by the turn developments took.

To look for the cause in deliberate manoeuvring by political or religious leaders does not make sense either. First, Sakka played no role whatsoever in the starting of the massive screening of the Tapanahoni Djuka; he merely resigned himself to the unusual expansion of the inquest. Secondly, Sakka was far away in his upstream bush camp when the witch craze really got under way. There is no doubt that his followers apprised him of the events at Poeketi; he probably was not in favour of it and hoped that it would just blow over. On the basis of what several informants told me - the testimony of his followers is particularly valuable - it appears that Sakka lost control of the situation. I will return to this later.

Another possibility could be the chief, Oseisie. Perhaps Oseisie set all this up to counter the great influence of his uncle Sakka on religious affairs. However appealing this supposition might be at first glance, there is little to substantiate it and much to refute it. Certainly, Oseisie had a motive in his dislike for the old caucus of religious bosses headed by Sakka. However, he did have neither the means nor the dedicated following to organise the happenings at Poeketi or enforce its decisions. Moreover, when an opportunity presented itself to get some grip on the Investigation Committee, he quickly sided with Sakka.

When queried about the persons who were in charge at Poeketi, informants were not very helpful. Although several sections of this account were related to me in great detail, they could not name the gravediggers who relayed the original message of the conspiracy Coba's ghost revealed. I now feel that it is useless to ask for the names of leaders or power groups in a search for explanation. The Coba enquiries and the happenings that surrounded it were borne by a mass movement, from its inception in the first two days after Coba's death until its sudden end three months later. Some of the evidence germane to this point will now be presented.

First and foremost, it was a movement widely supported by 
influential elders and gravediggers. Several teams of bearers had carried the corpse of Coba, meaning that support for the developments was widespread among the association of gravediggers which represents a fairly large section of the adult male population. The composition of the Investigation Committee itself guaranteed that many influential elders connived at it and perhaps even encouraged it. Later, when the screening test became obligatory, the cooperation of elders in all Tapanahoni villages was secured. In view of the prevailing system of village democracy, this by implication signified that a considerable portion of the adult male population looked with favour on the Poeketi enquiries.

The swift development of the enquiries, the absence of a prophet or any form of leadership, the cooperation of great numbers of elders and gravediggers, all indicate that this was a popular upsurge, a mass movement. But, as with every mass movement, some supported it more strongly than others. It is my contention that the backing for the enquiries came primarily from that section of the adult male population which had, during the preceding decade, become transport carriers for the gold industry of Surinam and French Guiana.

During the 1880 s, three successive gold rushes brought thousands of treasure hunters to the Lawa-Maroni basin of which the Tapanahoni forms part (Spalburg 1899: 8). The Bush Negroes who transported the gold-diggers and brought them the food and equipment they needed became rich quickly. They dreaded the witches more than anything on earth; they possessed wealth undreamed of before and feared that envious kinsmen and neighbours - less fortunate - were willing to go to any length to get a share of it.

What the Poeketi enquiries did for the boatmen was to externalise these fears. It was no longer an individual emotion gnawing at one's sense of security in the world: obviously, it was shared by hundreds of others. With every day's share of startling new disclosures, their fears increasingly appeared legitimate. Once anxieties were brought into the open, and the enemies had assumed concrete shape, they could be fought and properly dealt with through humiliation, fines and cleansing 
ritual. This is why Poeketi was so significant for the boatmen, economically the strongest group in Djuka society.

\section{Sakka strikes back}

As the investigation at Poeketi gained momentum, with hundreds of people journeying to the Coba oracle, Sakka was reposing at his bush camp 'Bilo Watta', not far from presentday Granbori. A message arrived which left Sakka thunderstruck: he was ordered to appear before the Coba oracle with all his children and dependents. Sakka, who had felt secure as the religious authority par excellence, was to submit himself to the judgement of the ghost of a witch and to his own Sweli obia! That, it must have been clear to Sakka, meant that the Investigation Committee felt strong enough to challenge him. Sakka had allowed control of the Sweli obia to slip from his hands; he had grievously underestimated the appeal of the Poeketi enquiries and the forces behind it. What was worse, he had allowed a new oracle to merge that was beyond his sphere of influence. For the first time in Djuka history, there was now a direct possibility to consult Sweli on witchcraft and other matters of interest, regularly and in public. Hitherto, a "carry oracle' of tribal stature ${ }^{16}$ had not been available. Now the bier with the decaying remains of Coba served as one. And, in the meantime, Sakka had gone fishing!

Sakka decided to redress the situation by regaining the initiative. He assembled all his dependents, as he was told to do, but travelled to Dritabiki, not Poeketi. It was a traumatic journey, which today is still engraved in the memory of descendants of Sakka as the hour of trial. In painful detail, grandchildren of Sakka recall the account he related to them, at which boat landings they stopped on their downstream journey, to whom they spoke, how they all had withdrawn from him. 'Father Sakka, no exception can be made for you, you have to appear before the Coba oracle, you and all your children'; said Da Nono at the Godo Olo landing. But Sakka was adamant and furiously rejected any notion that he or his 
dependents could be forced to undergo the witchcraft test: 'My children will not pass under the body of that dead woman that should have been thrown away three months ago; my children will not tolerate the gravediggers to carry the corpse around them! I have my own obia to work with.' This is what he told the elders at Godo Olo and at countless bush camps and other villages he passed, and this is what he threw in the face of Oseisie when the latter urged him to give in.

A few days after his arrival at Dritabiki, Sakka's preparations were completed. The only way to get the upper hand, he must have realized, was to offer the Djuka another 'carry oracle', but responsive to a more powerful obia, that would fulfill the same needs that the Coba oracle did. Sweli was not a good proposition; he had lost control over it. The Agumaga and Gaan Tata obia were too weak to help Sakka regain ascendancy; people were familiar with their ordinary powers and these clearly had not been enough. However, buried at Santi Goon was the great obia of the war of independence, the undiluted Gaan Tata or Gwangwella obia. Sakka concluded that the pure obia had to be disinterred.

Two problems had to be solved before Sakka could hope to have access to this powerful obia. First, there was the religious and technical problem of how to 'enrich' the diluted Gaan Tata obia until its strength was equal to the original one buried at Santi Goon. Additionally, the obia should be made available so that it could be employed as a carry oracle. The second task was to convince people of the authenticity and strength of the new oracle, no mean feat in view of the enormous popularity of the Coba oracle and the cooperation that the Investigation Committee had secured from Oseisie and other influential elders. Oseisie was informed by Sakka about his audacious project but he counselled against it: 'What is buried remains buried; the obia has caused too much strife in the past' (Morssink 1934). Oseisie kept insisting that Sakka submit himself to the Coba cum Sweli oracle.

Sakka got into his boat early one morning and headed for Santi Goon. He was accompanied by a few trusted followers, two of them his sister's children. To solve the first problem 
adequately, Sakka needed tools for the task. For this purpose, he had selected a relatively unknown Kumanti carry oracle. This was convenient since, primarily, it was owned by his matrilineal kin and secondly, because the Kumanti gods had come out of the grand investigation at Poeketi unscathed. At an open place in the forest at Santi Goon, the antechamber for the uninitiated, he ordered his followers to wait. He then walked over to the holy place, dug-up some objects connected with the Gaan Tata cult and returned to the antechamber. Now the Kumanti bundle, repository of the obia, was fastened to a plank and put on the heads of two bearers. Divination could begin. Its main purpose was to legitimize the undertaking and obtain directions from the Kumanti spirit on how to construct a new Gaan Tata or Gaan Gadu bundle. At the end of the day, Sakka and his small band of followers returned to Dritabiki with two obia: the Kumanti and the Gaan Gadu obia in a new and enriched form.

Now came his most difficult task, to persuade the Djuka, in the midst of euphoria, that they were wrong. With conviction, cunning and deceit, he succeeded remarkably. As one of his grandchildren related it:

After he had come back from Santi Goon, late one evening, Sakka went to the boat landing of Dritabiki, you know the muddy one. He carried a bottle of beer which he then hid by tying it to the underside of a boat. On the morrow, at the break of day, father Sakka walked over to Oseisie's house and said: 'Brother See (a diminuative), things happened to me yesterday, you wouldn't believe it, somebody pinched a bottle of beer of mine.' Oseisie replied: 'Well, that's your problem, uncle, look for the thief among your own children.' But father Sakka insisted that they would look into the matter jointly: 'I am sure that none of my children did it. But fortunately, I have a way of knowing now; I possess an obia that can decide for us. Let us carry this obia of mine and see what it says.'

The two men then took the paddle to which father Sakka had fastened a small bundle containing the obia. Oseisie placed the front side of the paddle on his head, father Sakka carried the back end of the paddle. (N.B. Oseisie had been given the most important position, the front bearer carries more responsibility than the hind one.) In this way, the two men had become the first bearers of Gaan Gadu.

The two men explained to the obia what had happened: 'a beer bottle had been lost, show us, obia where is it?' What the two men were really doing was to test the obia (den puubee a obia luku). Now came the first question: 'Did people from another village steal the beer bottle?' The obia, in reply, forced its bearers to move in circles. This was interpreted to mean that the one who took it away was from the same village. They then politely begged the obia to help them recover the bottle. The obia agreed to 
assist them. First, the obia pushed them into the river, straight to the same muddy landing. Upon arrival Oseisie asked: 'Where do you bring us. Where is the bottle? In one of the boats?' The obia moved its bearers sideways; a negative reply. - 'In the water then?' Obia: 'Yes'. - 'Under this boat?' Obia: 'Yes'. And they found the beer bottle.

Father Sakka was enraptured that the obia worked so well and Oseisie was equally impressed. However, the obia was dissatisfied. Obia: 'Now, let me speak. You two men appear to have tested me, as if you had no faith in me whatsoever. You will have to pay me for this lack of trust'.

Then, the obia pronounced that Oseisie had to pay twelve pangi (a cloth used by women as a wrap-around skirt, but also a traditional form of payment for fees and fines) and one wicker bottle with rum. Which accounts for why today witches have to pay, after treatment, the same amount and in these commodities. Father Sakka, however, had to pay much more. The obia reprimanded him for displaying so little trust when he should have known better: 30 pangi and six wicker bottles with rum, that is what our father Sakka had to pay!'

Now, the obia was ready to be shown to all people (fu tjai en a ganda). The following day, all the people of Lon Watta (area around Dritabiki, see fig. 2) had a chance to see for themselves what a wonderful carry oracle they had received. The questions to Gaan Gadu were put by father Sakka and Oseisie; a son of Oseisie and a son of Sakka's sister were the first regular bearers. And so we got our Gaan Gadu. ${ }^{11}$

When the first reactions of the people proved to be favourable, great council meetings were proclaimed for all Djuka of the Tapanahoni. For three days a great council (gaan kuutu) convened at Poeketi and for eight days at Dritabiki; both occasions were presided over jointly by Sakka and Oseisie dressed in the official uniform of the colonial administration.

One of the first decisions of the great council was to bury whatever remained of Coba. This was to be done in a shallow grave; a compromise between the burial of a witch whose corpse is left at an unholy spot in the jungle and the ordinary burial. Respect for Sweli, who had used the deceased so long as his vehicle, made the great council decide on this compromise.

More significantly, it was resolved by the great council that all decisions of the Coba oracle were to be honoured. The destruction of evil objects, the spirits that were removed, all these were applauded as great improvements in the quality of life. 'It lifted a weight from our chest to know that all these bad spirits were no longer around,' one informant recalled his mother telling him. 
For the pattern of future power relations, the mergers that Sakka executed were crucial. First, he managed to fuse the Agumaga and Gaan Tata obia. How he did this is unknown today, but politically speaking it was relatively easy as he firmly controlled both obia. The merger with Sweli must have been much more difficult. First, he had Sweli's vehicle, the body of Coba, buried. With the help of Oseisie and a few relatives, all of them Sweli priests, Sakka made his second move: Sweli was offered hospitality in the bundle of Gaan Tata. This probably was acceptable to the majority of Coba's supporters, as what they desired most was a 'religious machine' that would consolidate the gains of the past few months and give assurance of constant vigilance for the future.

Sakka, supported by Oseisie when events were developing favourably, had in one stunning blow reversed fortunes and was in command again. The Coba oracle was removed. The merger with Sweli guaranteed that no one could turn that cult as a weapon against him. While formerly he had been primus inter pares of the Sweli cult, after the merger his position was unassailable. The considerable prestige and legitimacy of the Sweli cult now came to reinforce the Gaan Tata or Gaan Gadu cult. The merger was so successful that the initiates called the combination of the three obia Agumaga - after the obia that had indisputably been Sakka's.

But it was no longer 'business as usual'. Poeketi, the Investigation Committee and its numerous followers had all surrendered to Sakka, but only after a price had been exacted; the radical reorientation of the tribal cults. What the 'speech-making community' of affluent boatmen demanded was a much more active priesthood, dedicated to the goal of eradicating witchcraft. The search for the 'enemies within the gates', as Mayer (1970: 62) once aptly called the witches in an African society, was to be the main preoccupation of gods and priests. From this point on total war would be waged on them. The boatmen were willing to pay handsome fees to Sakka and his colleagues, but they demanded protection of their lives, prosperity and reputation in return. It should be made clear at the new oracles that they, the boatmen, were vindicated as 
hard-working citizens of the Djuka nation who could walk upright. The new Gaan Gadu cult took over in toto the reforms that Coba's oracle and the Investigation Commitee had promulgated. He who pays the piper, calls the tune.

\section{Characteristics of the Gaan Gadu cult}

In 1890 , after years of steadily growing fears of witchcraft, the new Gaan Tata, Agumaga or Gaan Gadu was called upon to safeguard his people. After the successful merger with the Sweli obia, the Djuka but also the faithful from other tribes, had to enter into a covenant with Him by drinking the sacred potion (diingi Sweli or diingi Gadu). In this new form it remained the religion's main sacrament and ordeal; those who survived proved themselves worthy of God's protection, those who died were the witches. Two important differences with the past come to light here. Whereas formerly, during most of the 19th century, representatives of villages could take the oath or a few suspects who were called to make an appearance, now it was binding on every adult. Equally important, the rites were no longer defined predominantly as an oath of allegiance to the Djuka tribe. Supplicants from other tribes were also given the opportunity to drink the potion. One's first loyalty was to be to Gaan Gadu rather than to a particular tribe. The institution of oath taking was ancient, but its redefinition was radical. It reflected both the rising fears of witchcraft as well as the fact that Djuka, Saramaka, Aluku and Paramaka were now living and working in the same river basins of Surinam and French Guiana, sharing bush camps for a night stop and assisting each other in passing the rapids.

The new cult brought a view of man's destiny and of the character of their supreme deity that was astoundingly novel and unfamiliar to the Bush Negroes. Whereas formerly man's success and peace of mind hinged on a proper compromise between the claims of diverse supernatural agencies, now devotion could be primarily reserved for Gaan Gadu. This God not only scrutinized their deeds, as did the supernatural 
beings of a traditional cosmology, but followed their thinking and feeling as well. Gaan Gadu was the deity 'that looked down into their hearts' and from whom no evil thoughts could be hidden. This was a most revolutionary notion and moreover, pertinent to the first task of the new movement - to smell out the witches.

Barring a few exceptional cases, witches were not believed to be driven by an inherited constitution which would predispose them for such heinous crimes (Van Wetering 1973: 84). It was rather a state of mind that would prompt men to harm the interests of his relatives and neighbours. Each misdeed would pave the way for a graver one; the propensity to commit witchcraft grew like cancer in the body, feeding on it and ultimately destroying it. It was a process of gradual moral corruption that often took years to reach its climax in the person of a witch fully determined to destroy life and well equipped to do so. But along the road to this final station there were places where the individual could resist temptations and turn back. Hence, a corollary of the theological notion of the omniscient God was the probing of conscience by the faithful. One could search one's heart for feelings of envy, hatred and resentment, for a grudge harboured too long. The notion of guilt was not foreign to Bush Negro religious life, but the way it came to predominate other feelings certainly was. The emphasis on the individual who could only at great pains and with perpetual inner scrutiny keep to the narrow road, was equally novel. Transgression of the commandment 'Thou shall not commit witchcraft' would entail a witch's death; the most dishonourable death for a Djuka (wisi dede). As in the past, the corpse of the deceased would be cast away in the jungle, the estate confiscated and a considerable part dumped at a sacred spot next to the Gaan Gadu bush shrine at Santi Goon.

Other moral injunctions were enforced by Gaan Gadu as well. These included suicide attempts, physical aggression, adultery, homosexuality and the transgression of the taboo on menstrual seclusion. These were punished by Gaan Gadu with illness and in serious cases with death. A demise for such reasons would be classified as a 'sinner's death' (misi dede). This 
was a novel category as formerly one could either die as a witch or as a respectable person (jooka dede). A deity taking such an interest in all spheres of life was unusual, and the same can be said of the stern, disciplinarian image of the deity that Gaan Gadu's priests assiduously cultivated. From the first years following its inception we have reports mentioning that men were flogged for hitting their wives or even for coming too late to a religious convocation. All were measures taken in the name of Gaan Gadu.

The confiscating of legacies and the discarding of a witch's corpse in the bush were ancient institutions that had been part of the Sweli cult for a very long time. What the events at Poeketi did was to intensify greatly the use that was made of these practices. Formerly, the posthumous condemnation had been exceptional; now it seemed to become the rule. Between 1961 and 1970, when the Gaan Gadu cult was still flourishing in the Tapanahoni region, $50 \%$ of all deceased persons were posthumously condemned as witches (Van Wetering 1973: 57). An enormous volume of confiscated goods was brought to Santi Goon.

Nowadays, the Djuka are well aware of the changes wrought at Poeketi. They summarize it by saying 'Sister Coba created Santi Goon' (Sa Coba ben meke Santi Goon). The gravediggers and Investigation Committee at Poeketi created an atmosphere of emergency, and neither Sakka nor anybody else would have been capable of dispelling it even if they had wished to do so, which they did not. Sakka could only give direction to the apprehensions by having the holy bundle of Gaan Gadu operate as the Coba oracle functioned before, a spearhead in combatting witches. Coba's death therefore marked a watershed in Djuka history and it makes sense to divide it into two periods: before and after Coba. 


\section{Aftermath}

What happened after the founding of the Gaan Gadu oracle is better known. One of the first decisions made was to export the cult to other regions where Djuka had settled and to other Bush Negroes as well. This missionary drive was related to the new theological ideas, in particular to notions about the supreme deity and the universal and omnipresent character of evil. The Djuka of the Tapanahoni saw the new creed as absolutely essential for the survival of all Bush Negroes, not as something of only parochial or tribal significance. Such sentiments were reinforced by the obvious gain the hieratic leadership was to have from a new stream of supplicants, and from the share that they could take from the legacies of dead witches.

In 1891, several meetings were held at various places throughout the coastal area to familiarize the Bush Negroes with the new creed. In particular, people were urged to free themselves from the shackles of possessing spirits by pushing their shrines into the river and burning their amulets. That is what many proceeded to do. The complete inauguration of new branches of the cult had to wait until 1893. In that year, a delegation of Cottica elders under the leadership of their headman Brokohamaka journeyed to the Tapanahoni. After a six months' stay they returned with the carry oracle and other required cult objects. Upon his return in September 1893, Brokohamaka convened a gathering of all Cottica Djuka to disclose what divine pronouncements had been given on the Tapanahoni a few years earlier. In 1893 and 1894, Buck (MT 1895: 47-54; MT 1896: 65-79), a missionary who often visited Moarimbomoffo from the nearby mission post at Wanhatti, could observe that key institutions of the Gaan Gadu cult had already been introduced in the Cottica region at that early stage.

That the new cult swiftly gained acceptance in other Bush Negro regions, can be inferred from the entries in Spalburg's diary (1896-1900). At that time he noticed the presence at Dritabiki of Saramaka, Paramaka, a few Creoles from Para- 
maribo and Cayenne, and many Djuka from the Cottica and Commewijne regions. All these people were attracted by the new Gaan Gadu oracle.

Well known and much written about is the rift that opened between the two top men of the Gaan Gadu movement in 1891 . What exactly caused the trouble is not fully understood. As discussed above, some hold that the enormous raise in Oseisie's annual salary from the Dutch, irked Sakka (Van Lier 1919: 49). It was also contended that the trouble flared up when Oseisie began to demand a bigger share of the emoluments received by the Gaan Gadu priests. Nowadays, descendants of Oseisie present a view that is predictably different from that of Sakka's grandchildren. But both seem to be right when they explain: 'People with long noses cannot kiss'.

There is no doubt about the upshot of the confrontation between the two big men. Sakka took his carry oracle and, together with his relatives, founded the village of Granbori in 1891. Djuka from various villages joined him, particularly those of the Lon Watta section. For Dritabiki, the consequences were an unmitigated disaster: a whole quarter of the village, where the relatives and elders of Sakka had stayed, suddenly was deserted. Dritabiki, denuded of its most powerful obia, could attract few patients and supplicants. The Bush Negroes Spalburg met in the village were on their way to the Gaan Gadu oracle at Granbori; they paid their respects to chief Oseisie by spending a few days in the village. In other cases, patients were told by Sakka to wait for a call before they would move to Granbori. In this way, the once important village of Dritabiki became a mere antechamber for Granbori. Its prestige and function so declined that, between 1896 and 1900, Oseisie himself spent as much time in Sakka's village as in his own residence (Spalburg 1896-1900). ${ }^{18}$ Oseisie clearly had been the loser in this encounter. From approximately 1893, Sakka's prestige was further enhanced by Ma Fiida, a healer, visionary and medium that claimed to be possessed by a spirit sent by Gaan Gadu himself. Countless patients flocked to Granbori to be treated by her.

Shortly after 1900 , Oseisie managed to fabricate his own 
Gaan Gadu bundle and oracle in more or less the same way as Sakka had done a decade earlier. He was assisted by defectors from Sakka's camp who accompanied the chief on his trip to Santi Goon and provided him with secret information on how the first bundle had been composed. Now there was real trouble on the Tapanahoni. Sakka threatened to stop all traffic of Oseisie supporters to the Amerindian territory closer to the Brazilian border, a favourite area for hunting and fishing and for buying hunting dogs from the Amerindians. Oseisie warned Sakka that such a drastic step would meet with instant reprisal: no inhabitant of Granbori would be allowed to pass Dritabiki on his way to the coast.

A reconciliation was finally arrived at which left Oseisie in a much better position. From then on, the parties would recognize both the Granbori and Dritabiki oracles as authentic mouthpieces of Gaan Gadu. A great feast of atonement took place at Dritabiki in September 1903. Thereafter, two Gaan Gadu oracles, one at Dritabiki and one at Granbori, were in operation. Recently, in 1972, a new religious leader ${ }^{19}$ put an end to the activities of the Gaan Gadu oracles of the Tapanahoni river.

\footnotetext{
Acknowledgements. This paper is mainly based on field research among the Djuka of the Tapanahoni area of Surinam. It took place from June 1961 till November 1962, during August 1965, in September and October 1970, in December 1973 and January 1974 and again in April 1977. I have drawn on the field notes of Wilhelmina van Wetering, my colleague in a long-term study of Djuka society. Dr. James Park generously shared his knowledge of the Tapanahoni Djuka with me. For comments on this paper I wish to thank Chris de Beet, Miriam de Beet-Sterman, Gary Brana-Shute and especially Rosemary Brana-Shute. None of them should be held responsible for my interpretation of Djuka history.

The research was financed by The Netherlands Foundation for the Advancement of Tropical Research (WOTRO) and the University of Utrecht.
} 


\section{NOTES}

1. The Bush Negroes, or Maroons, are descendants of slaves brought to Surinam from West Africa. Their ancestors escaped from the plantations, fought a successful guerilla war against the Dutch planters and their mercenaries and managed to establish semi-independent tribes in the interior. The most populous of the six Bush Negro tribes are the Djuka and Saramaka, each now numbering between 15,000 and 20,000 (Price 1976: 3). In 1900, estimates for the Djuka population ranged between 3,000 and 4,000. The Djuka have founded their villages both in the hinterland, along the Tapanahoni, Maroni and Lawa rivers, and in the coastal plain, along the Cottica, Commewijne and lower Saramacca rivers (see Fig. 1).

The geographical position of the other groups is as follows:

the Saramaka, in the centre of the country along the Suriname river and its tributaries; the Matawai, a much smaller group (population approximately 1,800 ) along the upper reaches of the Saramacca river;

The Aluku or Boni on the banks of the Lawa river (approximately 1,500); the Paramaka along the central part of the Maroni river (population 2,000);

the Kwinti along the Tibiti, Coppename and Saramacca rivers (population about 300).

Figures for Saramaka are taken from Price (1976: 3); for Paramaka from Lenoir (1973: 1); for the Matawai and the Saramacca K'vinti I rely on the demographic knowledge of Chris and Miriam de Beet; for the Coppename Kwinti on Van der Elst (1975: 14), while the Aluku or Boni figures were obtained by doubling Hurault's (1960: 40-41) 1958 census count.

2. The name Gaan Tata has fallen into disuse. Nowadays, the Djuka usually refer to Gaan Gadu or Bigi Gadu (Thoden van Velzen 1966). Kersten, a missionary who visited the Tapanahoni in 1895 (MBB 1896: 195), noted that the name Gaan Gadu was used by the high priest Da Labi Agumasakka ('Sakka') as a synonym for Gaan Tata. Other names mentioned in the earliest accounts of the movement are Massa Jehovah and Bakaa (MT 1895: 52), respectively 'Sir Jehovah' and 'European' or rather 'Outsider'. I will employ the name Gaan Gadu for the movement that spread through Surinam in the early 1890s. As I will presently explain, the Gaan Tata was merely one of the constituting cults within the framework of the Gaan Gadu movement.

3. Spalburg (1896-1900) counted 42 Saramaka at Dritabiki between the months of July and November 1896. They were on their way to the main Gaan Gadu oracle, then situated at Granbori. Other entries in Spalburg's diaries also point to the presence of Saramaka for worship of Gaan Gadu on the Tapanahoni river (cf. May and August 1899). See also Spalburg (1899: 38).

4. Personal communication, Chris de Beet and Miriam de Beet-Sterman.

5. Leerdam referred to a much earlier phase in the history of the Gaan Gadu cult, probably to the early 1920 s.

6. Most notably Leerdam (1957), Van Lier (1919) and Morssink (1934).

7. Both accounts predominantly use the name Gaan Tata, irrespective of the period discussed. Although there is nothing wrong with such usage, I prefer the name Gaan 
Gadu for the movement that had so much success in the 1890 s. I will have occasion to argue that the movement contained features that were radically new, and that it would be helpful to distinguish it from the Gaan Tata cult which must have existed for the better part of the nineteenth century.

8. Van Lier (1919: 54) mentions September 1902 as the date for the reconciliation feast and referred to the testimony of the surveyor Samson, who was an eye-witness of the scene. From Polak (1908: 244), however, we know that Samson's visit to Dritabiki occurred in September 1903.

9. Here is an entry from Morssink's manuscript: 'The older men were accustomed to an easy and comfortable life, surrounded by their many wives, but without doing any hard work!' (Now they were thinking:) 'How can we keep the younger generation in subjection? How? By rehabilitating Gaan Tata and so Sakka proceeded to advise them, not without Oseisie's consent'.

10. From detailed historical information kindly made available to me by Michel Aboikoni and Richard Price, it appears likely that the Saramaka villages of Kampu and Dangogo had adopted Gaan Tata worship before 1890. Many years later, the exact date is difficult to give, the Tapanahoni Djuka urged these Saramaka to accept a number of religious innovations from them. Most notable among these was the "carry oracle'; a divination technique of central importance in the new Gaan Tata or Gaan Gadu movement of 1890 . The 'carry oracle' was not employed by adherents of the old Gaan Tata cult.

Albitrouw (1892-1896) reported the upheaval by the messianic prophet Paulus Anake in the village of Sophieboeka or Dombikonde (see Fig. 1) along the central section of the Suriname river. In particular, Paulus Anake rebelled against the Gaan Tata cult which had a firm grip on village life; its custodians in Sophieboeka were Anake's parents. Judging from its central taboos, particularly those relating to menstrual seclusion and avoidance, a connexion with the early Gaan Tata cult of the Djuka appears likely.

11. Brunetti (1890) did not mention Sakka's name but it is clear from the account, with such particulars as 'the influential uncle' and 'the uncle speaking on behalf of the great council,' that only Sakka could be meant.

12. This account is, to a very large extent, a summary of what five key informants told me. Two of them clearly belong to the Granbori group; one of grandson of Sakka, the other his foster son. They were interviewed separately in April and May 1977; the first at Dritabiki, the latter at Albina on the coast where he lives in exile after becoming a persona non grata with some other infuential descendants of Sakka. Predictably, these two informants present us with Granbori's view of recent Djuka history; an angle that has not been used previously for the reconstruction of the Djuka past. Two other key informants were found in Dritabiki. They are both members of the Misidjan clan, but are born in different lineages (Dalaa and Masaa respectively). Both men had been informants during several periods of research in the past and, when confronted with statements from Granbori informants, volunteered new information that they had never thought fit or suitable to intimate to Bakaa (non Bush Negroes) before. The fifth key informant comes from the Pataa clan and formerly resided in the village of Loabi; today he occupies an important position in the Akalali movement (Thoden van Velzen 
\& Van Wetering 1975). His contribution is particularly valuable because his clan and village had not been party to the Dritabiki-Granbori strife.

13. The chronology is not easy to establish. What we can indicate, however, are a bottom line and a ceiling within which the death of Coba and subsequent events have to be placed. As for the ceiling, the events related could not have happened after the middle of 1891. Carpenters from Paramaribo, building the mission post at Wanhatti on the Cottica river, witnessed an extraordinary gathering during these months. The approximately 300 Djuka who attended it swore allegiance to Gaan Gadu; they destroyed their amulets and other vessels of obia and promised to observe the new moral norms faithfully (BHW 1892: 139-144). This is the first published account confirming the existence of the new cult. All other communications that give information on the Gaan Gadu movement were from later years, for example 1892 or 1893.

For the bottom line, I rely on the repeated and explicit assurances of all five main informants that Coba's death and the great convocations marking the beginning of the Gaan Gadu religion took place after the inauguration of Oseisie as chief and Sakka as village headman. This is supported by Morssink's informants (1934) who stated that Sakka and Oseisie attended the convocations in the uniform given them by the colonial government. Oseisie had taken up his office in 1884, but it took the colonial administration till October 1888 before they inaugurated him. After this ceremony neither Oseisie nor Sakka seemed in a hurry to get back to their Tapanahoni villages. In fact, one of the reasons for the colonial government to offer Oseisie and his numerous following free transport by ship back to Albina - the first stage of their return trip was to get these boarders off the government expense account. Upon his arrival at Albina, Oseisie again showed no eagerness at all to return to the Tapanahoni. In January 1889, he was still in Albina pressing charges against some Saramaka boatmen that had aroused his displeasure (LA/14-1-'89/252).

In view of the fact that the Coba enquiries by themselves took several months; considering the time involved in the great council meetings that marked the beginning of the Gaan Gadu cult and allowing for the considerable time required for sending delegations to the Cottica river and convening the meeting near Wanhatti, it seems likely that Coba's death occurred before the end of 1890 . My hunch is that Coba died sometime in the middle of 1890 . Most of the second half of that year was taken up by the enquiries, Sakka's manoeuvres, the ensuing palavers and the convocation that sealed the birth of the cult. Then, early in 1891, the Gaan Gadu movement spread through the hinterland with the force of an explosion.

14. One informant (from the Pataa clan) insisted that it was not Sweli who 'mounted' Coba but 'A Ogi;' that is to say, the central deity of the new Akalali cult. In view of the important position the informant occupies in the last cult, this did not come as a surprise. What this statement attests to is the enormous significance that the Coba enquiries still have in the mind of Djuka notables today.

15. Nowadays, the exorcist wave is referred to as Coba puu sani - Coba took away (evil) things.

16. A number of 'carry oracles' existed before 1890 in the Tapanahoni region. Brunetti (1890: 207) saw one in operation in the village of Malobbi (near Tabiki) in 1886. Such 'carry oracles' did not enjoy tribal fame and recognition. 
17. For those unfamiliar with Bush Negro religion, the scene must seem a crude mixture of burlesque and quackery. Yet for an intelligent man like Sakka, and for the majority of the Djuka who came to hear about it, it had none of these qualities. For example, the informant who related this account asked me several times whether I was not impressed by the powers of the obia. Only a few moments earlier the same man had explained in great detail how Sakka had prepared the occasion by hiding the bottle himself. For this informant, there was no contradiction or swindle. Two remarks about this divination may be germane here. In the first place, Sakka believed in the powers of the Gaan Gadu obia, but he faced the problem of convincing Oseisie quickly. With the implications of the Poeketi enquiries becoming clearer everyday, Sakka was a man in a hurry. He had no time to wait for the wavering Oseisie to be persuaded by 'ordinary' supernatural proof; that is, by the evidence provided by a number of standard divinations on the causes of affliction and subsequent cases of healing and recovery. Every day counted and Sakka intended to speed things up. Secondly, and equally important, Sakka had asked Oseisie to take the front position in the carrying of paddle and bundle. The front bearer is the one generally held responsible for proper divination. If fraud takes place, and the Djuka hold that some bearers occasionally resort to it, then it is nearly always ascribed to the front bearer. Sakka considered the test to be additional proof of the obia's worth as it is believed that the forces emanating from the bundle press most strongly on the front bearer. Sakka probably felt he had eliminated unneccesary risks by hiding the bottle himself; in that way he knew whether Oseisie was rendering the obia's directives correctly. If Oseisie had attempted to distort the divination, Sakka could have checked it from his position as hind bearer.

18. Between August 1896 and June 1899, Oseisie spent at least $50 \%$ of the time in Granbori with Sakka. During some months, for example in February 1899, Spalburg, the Moravian teacher, was the only resident of Dritabiki. The villagers either spent their time in their bush camps or were at Granbori (Spalburg 1896-1900).

19. In 1972, Akalali, a man from the Pataa clan, accused the Gaan Gadu priests of corruption. With the backing of popular support he stopped work at the Gaan Gadu oracles of Dritabiki and Granbori, forbade the carrying of corpses and posthumous punishment of witches and desecrated Santi Goon. He founded a new cult which has $A$ Ogi (The Evil) as its supreme godhead. The priests of this cult reside in Njoen Konde, a few kilometres upstream from Dritabiki. They operate 'carry oracles' and have, as their predecessors, given considerable time to the detection of witches (Thoden van Velzen and Van Wetering 1975). The movement has spread from the Tapanahoni to other Bush Negro regions. 


\section{REFERENCES}

Abbreviations for journals and archival sources:

BHW Berichten uit de Heiden-Wereld

LA Landsarchief Paramaribo

MBB Missions-Blatt aus der Brüdergemeine

MT Mitteilungen aus der Brüdergemeine

NB Nachrichten aus der Brüdergemeine

Albitrouw, Izaak, 1900. Tori vo dem bigin vo Anakee en moro fara. Manuscript.

Brunetti, Jules (Le R.P.), 1890. La Guyane Française. Souvenirs et Impressions de Voyage. Tours: Alfred Mame et Fils.

Buck, G., 1896. Bilder aus dem Leben der Djuka-Neger an der oberen Cottica in Suriname. MT 1896 (2): 65-79.

Coster, A.M., 1866. De Boschnegers in de kolonie Suriname. Hun leven, zeden en gewoonten. Bijdragen tot de Taal-, Land-en Volkenkunde van Nederlandsch Indië 3: 1-36.

Franssen Herderschee, A., 1905. Verslag van de Tapanahoni-expeditie. Tijdschrift van het Koninklijk Nederlandsch Aardrijkskundig Genootschap 22: 847-1032.

Freytag, Gottfried A., 1927. Johannes King der Boschland-Prophet. Ein Lebensbild aus der Mission der Brüdergemeine in Suriname. Herrnhut: Missionsbuchhandlung.

Goeje, C.H. de, 1908. Verslag der Toemoekhoemak-expeditie. Tijdschr. Kon. Nederl. Aardr. Gen. 25: 995-1169.

Groot, Silvia W. de, 1975. Conflictsituaties. De Marrons in Suriname (sedert de $18 \mathrm{e}$ eeuw). Overeenkomsten en verschillen met andere Caraïbische gebieden. In: Suriname: van slavernij naar onafhankelijkheid. Uitgave van de Stichting ter bevordering van de studie der Geschiedenis in Nederland (SSGN). Wetensch. publ. 3.

Groot, Silvia W. de, 1977. From Isolation towards Integration. Verhandelingen van het Koninklijk Instituut voor Taal-, Land- en Volkenkunde 80. The Hague: Martinus Nijhoff.

Hartsinck, Jan Jacob, 1770. Beschrijving van Guyana of de Wilde Kust in Zuid-Amerika. Amsterdam: Gerrit Tielenburg.

Hostmann, F.W., 1850. Over de beschaving van Negers in Zuid-Amerika door kolonisatie met Europeanen. Amsterdam: J.C.A. Sulpke.

Hurault, Jean, 1961. Les Noirs Réfugiés Boni de la Guyane Française. Mémoires de l'Institut Français d'Afrique Noire 63. Dakar.

Junker, L., 1961. (Letter to Fr. Morssink dated April 16, 1923). Archives of the Bisdom of Surinam at Paramaribo. 
Junker, L., 1925. De godsdienst der Boschnegers III. De West-Indische Gids 7: 153-164.

Kersten, 1896. 'Suriname'. MBB 60: 97-108, 150-160, 179-190, 207-223.

Kőbben, A.J.F., 1967. Unity and Disunity: Cottica Djuka Society as a Kinship System. Bijdr. Taal Land Volkenk. 123: 10-52.

Kraag, Christiaan, 1894-1896. Diarium Copenkrissi. Archives of the Moravian Brethren; National Archives of the Netherlands at Utrecht.

Leerdam, H., 1957. Onze Boslandbewoners: het godsdienstig leven. XXVII. De West 23.IV.1957, Paramaribo.

Lenoir, J.D., 1973. The Paramacca Maroons. A Study in Religious Acculturation. Ph. D. Dissertation. The New School for Social Research, New York.

Lenoir, J.D., 1974. Politics of Christianity and obia in a Surinam maroon society. Paper presented at the 73rd Annual Meeting of the American Anthropological Association, Mexico. MS.

Lier, W.F. van, 1919. Iets over de Boschnegers in de Boven-Marowijne. Paramaribo: H. van Ommeren.

Mayer, Philip, 1970. Witches. In: Max Marwick, Witchcraft and Society, p. 45-64. Harmondsworth: Penguin Modern Sociology Readings.

Morssink, F., 1934. Boschnegeriana 3: Djoeka's of Aukaners. Manuscript.

van Panhuys, L.C., 1908. Iets over de Marowijne-rivier en hare geschiedenis. Haarlem: Ketting (2nd edition).

Polak, J.A., 1908. Historisch overzicht van de goudindustrie in Suriname. The Hague: Martinus Nijhoff.

Price, Richard, 1976. The Guiana Maroons. A historical and bibliographical introduction. Baltimore: The John Hopkins University Press.

Rattray, R.S., 1927. Religion and Art in Ashanti. Oxford: Clarendon Press.

Schneider, H.G., 1893. Die Buschneger Surinames. Herrnhut: D.G. Warned (2nd. edition).

Spalburg, J.G., 1896-1900, Diarium Drietabbetje 1896 - April 1900; De laatste reis, 1908. Archives of the Moravian Brethren; National Archives of The Netherlands at Utrecht. Hpt. Abt. IIB C II 1,2.

Spalburg, J.G., 1899. Schets van de Marowijne en hare Bewoners. Paramaribo: H.B. Heyde. 
Steinberg, H.G., 1933, Ons Suriname. De Zending van de Evangelische BroederGemeente in Nederlandsch Guyana. The Hague: Algemeene Boekhandel voor Inwendige en Uitwendige Zending.

Thoden van Velzen, H.U.E., 1966. Politieke beheersing in de Djuka maatschappij: een studie van een onvolledig machtsoverwicht $\mathrm{Ph}$. D. dissertation. Amsterdam: Antropologisch-Sociologisch Centrum.

Thoden van Velzen, H.U.E., 1977. Bush Negro Regional Cults: A Materialist Explanation. In Richard P. Werbner, Regional Cults. A.S.A. monographs 16, London: Academic Press.

Thoden van Velzen, H.U.E. \& Wetering, W. van, 1975. On the political impact of a prophetic movement in Surinam. In W.E.A. van Beek \& J.H. Scherer, Explorations in the Anthropology of Religion; Essays in Honour of Jan van Baal. Verh. Kon. Inst. Taal Land Volkenk. 74.

Van der Elst, Dirk H., 1975. The Coppename Kwinti: notes on an Afro-American tribe in Surinam. I, History and Development. Nieuwe West-Indische Gids 50: 7-17.

Voorhoeve, J. \& Renselaar, H.C. van, 1962. Messianism and Nationalism in Surinam. Bijdr. Taal Land Volkenk. 118: 193-216.

Wetering, Wilhelmina van, 1973. Hekserij bij de Djuka: een sociologische benadering. Ph. D. diss. Amsterdam: Antrop.-Sociol. Centrum.

Ziel, H.F. de, 1973. Johannes King: Life at Maripaston. Verhand. Kon. Inst. Taal Land Volkenk. 64. 